\title{
38. RED SEA GEOCHEMISTRY
}

\author{
Frank T. Manheim ${ }^{1}$, U. S. Geological Survey, Woods Hole Oceanographic \\ Institution, Woods Hole, Massachusetts
}

\begin{abstract}
The Red Sea drillings reveal a number of new facets of the hot-brine-metalliferous system and other geochemical aspects of the sea, its sediments, and its past history as follows:

1) Dark shales rich in organic material, and containing enhanced $\mathrm{Mo}$ and $\mathrm{V}$ concentrations, are characteristic of Plio-Pleistocene strata in the Red Sea. Values as high as $1500 \mathrm{ppm}$ $\mathrm{V}$ and $500 \mathrm{ppm}$ Mo were obtained in sediments containing up to 8 percent organic carbon.

2) Metalliferous sediments in the hot brine deep (Site 226) are similar in composition in both solids and interstitial water to previously analyzed sediments. However, one site (228) well south of the known hot-brine deeps shows zinc mineralization reaching 5 percent $\mathrm{Zn}$ in late Miocene shale-anhydrite breccias.

3) Pore fluid studies show that near-saturated $(\mathrm{NaCl})$ brines having similar total salt concentration to the hot-brine fluids are associated with Miocene evaporites at Sites 225, 227, and 228. However, their chemical and isotopic composition precludes such fluids being part of the "hot brine plumbing system." Hydrogen and oxygen isotope studies demonstrate that fluids trapped between and among the evaporitic rocks have a strong meteoric water component, presumed to have entered the rocks during or shortly after formation in shallow evaporating pans. The composition of pore fluid at Site 227 suggests the presence of late-stage evaporite minerals of the tachyhydrite $\mathrm{CaMg}_{2} \mathrm{Cl}_{6}$.
\end{abstract} $12 \mathrm{H}_{2} \mathrm{O}$ series in the in situ rocks.

4) Diffusivity measurements show that the pre-Miocene strata permit dissolved salt or gas diffusion to the extent of from $1 / 2$ to about $1 / 10$ the rate in free solution. However, in anhydrites diffusivity is reduced more than 100 -fold, and no diffusion could be detected through halite rock. The rates applied to interstitial salt gradients at Site 225 suggest that less than 1 meter of rock salt is removed per million years by diffusion processes. The diffusion of salt can already be detected a few meters below the sediment-water interface, and based on the interstitial water studies, one can affirm the presence of salt at depth at Sites 228, 230 , and possibly 229 , where rock salt was not encountered by the drill.

5) Isotopic measurements on leads show that both leads from Site 228 and the hot brine deep (Site 226) require input from igneous or volcanic sources (e.g., volcanic ash). Elsewhere, however, leads of sedimentary-pelagic origin are noted.

6) Isotopic and other evidence indicates that the long-distance transport of subterranean brines advocated by Craig (1969) is unlikely. Instead, it is proposed that the source of the hot brines is subevaporite clastic or other aquifers of early to middle Miocene age that have been disrupted by rifting. These discharge in the deeps by virtue of hydrodynamic continuity with heavy brines at higher positions on the nearby flanks of the Red Sea. In this case, the waters might be fossil (middle Miocene) Red Sea waters of relatively normal salinity that have acquired greater salt concentration by diffusion from overlying late Miocene

\footnotetext{
${ }^{1}$ Contribution No. 3213 of the Woods Hole Oceanographic Institution. Publication authorized by Director, U. S. Geological Survey.
} 
evaporites. The model is consistent with the isolated nature of the brine deeps and suggests that flow might have been enhanced by increased hydraulic gradients during periods of lowered Red Sea levels.

7) Interstitial water evidence indicates that Pleistocene lowerings of sea level did not cause evaporative conditions leading to actual gypsum or other evaporite deposition in the deeper water zones, as has been postulated. This in turn suggests that sill depths were greater than have been assumed.

\section{INTRODUCTION}

In order to get a broad coverage of pertinent data on the Red Sea hot-brine-metalliferous systems and associated geochemical phenomena, a two-fold strategy was employed: an emission spectrograph was placed onboard to perform immediate shipboard analyses of more than 23 elements. These data served both to orient geochemists and sedimentologists in the composition of various types of phases as they were encountered and to guide selection of samples and types of further analyses to be performed on-shore in supplemental studies. The rapidity of the visual, semiquantitative spectrochemical technique, employed by D. Siems of the U.S. Geological Survey, permitted assay of nearly every lithologic type of sediment or rock, as well as small particles, minerals, and organisms picked out under the microscope by paleontologists and petrologists. It also permitted early detection of anomalous boron and magnesium concentrations in interstitial brines, by analysis of the dried brine salt. In addition to spectrography, added emphasis was placed on the interstitial water and water sampling programs, and regular measurements of electrical resistivity of minimally disturbed cores were performed in order to obtain an estimate of their diffusive permeability to dissolved species according to previously described methods (Manheim and Waterman, in press).

In addition to the geochemical interests of the shipboard party, especially P. Stoffers and R. Coleman, who performed special studies of evaporitic rocks and basalts, respectively, samples were distributed to shore laboratories for the following surveys:

Chemical composition of sediments (major inorganic constituents): F. T. Manheim, U. S. Geological Survey, Woods Hole; U.S.G.S. laboratories, Washington, D.C.; Exploration Geochem. laboratories, Denver)

Lead isotope studies on sediments and brines: B. Doe, U.S.G.S., Denver

Sulfur isotope studies: I. R. Kaplan, U.C.L.A.

Uranium isotope studies: T. L. Ku, University Southern California

Carbon and oxygen isotope studies on sediments and interstitial waters: J. R. Lawrence, Lamont-Doherty Geological Observatory

Carbon and oxygen isotopes on small samples of separated foraminifera: W. A. Deuser, Woods Hole Oceanographic Institution

Deuterium content of interstitial waters: I. Friedman, U.S.G.S., Denver

Interstitial water studies on minor and trace constituents: B. J. Presley, Texas A \& M University

Interstitial water studies, major constituents: F. T. Manheim, F. L. Sayles, and L. S. Waterman, Woods Hole
Light hydrocarbons in canned samples: R. D. Mclver, Esso Products Research Corp.

Carbon isotopes in gases, and general gas composition: I. R. Kaplan, U.C.L.A.

Studies of rare earths in evaporites: J. L. Bischoff, University of Southern California

Potassium-argon "age" determinations on sediments: Geochron Laboratories, Cambridge, Mass.

The available results of these workers and their colleagues are included in this volume.

During the preparation of this Initial Reports volume, a summary of the main Valdivia discoveries of new brine pools and hydrothermal sediment sites appeared (Bäcker and Schoell, 1972); also, thin sections from basaltic rocks from drill holes off the Sudanese and Ethiopian coasts were made available by C. Burk of Mobil Oil Co.

Special thanks are due to the Analytical Laboratories of the United States Geological Survey, Washington, D. C., the Laboratory of the Geochemical Exploration Branch, Denver, for their extensive analytical assistance, and B.F. Jones (Arlington, Va.) and Omer Raup (Denver) for their help and discussion. Numerous discussions and communications with colleagues, both on shipboard and in associated shore laboratories, are acknowledged. Finally, I should like to thank Rebecca Belastock for assistance in calculations and D. A. Ross for providing manuscript materials.

\section{COMPOSITION OF THE SEDIMENTS}

Where sufficiently numerous and representative, the shipboard semiquantitative analyses (Manheim and Siems, this volume, Tables 1 to 5) may be averaged to make means with enhanced quantitative value: a rule of thumb is that the probable error of the mean is $E \sqrt{N}$, where $E$ is the mean error of the individual analyses and $N$ is the number of analyses. This presumes absence of significant systematic error; i.e., random scatter about the true values. The shipboard spectrochemical data, together with supplementary data on $\mathrm{Zn}, \mathrm{As}$, and a few other constituents, have been utilized to prepare means characterizing the sites stratigraphically and lithologically. Summary tables are also provided to include the quantitative (rapid rock) analyses and other shore laboratory data (Manheim and Siems, this volume, Table 6).

\section{Black Shales}

One of the discoveries of the shipboard analyses was that pre-Miocene black shales rich in organic material contain unusual concentrations of vanadium (V) and molybdenum (Mo) similar to other V-and Mo-rich organic shales famous in the geologic record. Such shales and their elemental concentrations include the following: 
Mean conc. (max. and min.) (ppm)

\begin{tabular}{|c|c|c|c|c|}
\hline $\begin{array}{l}\text { Name and } \\
\text { Location }\end{array}$ & $\begin{array}{l}\text { Org. } \\
\text { C(\%) }\end{array}$ & V & Mo & Reference \\
\hline $\begin{array}{l}\text { Kupferschiefer, } \\
\text { N. Germany }\end{array}$ & 6.5 & $\begin{array}{l}1700 \\
(5300-200)\end{array}$ & $\begin{array}{l}300 \\
(1500-14)\end{array}$ & $\begin{array}{l}\text { Wedepohl } \\
\text { (1964) }\end{array}$ \\
\hline $\begin{array}{l}\text { Swedish "Alum } \\
\text { shale," C }\end{array}$ & 17.1 & $\begin{array}{l}1500 \\
(3600-100)\end{array}$ & $\begin{array}{l}89 \\
(300-25)\end{array}$ & $\begin{array}{l}\text { Landergren } \\
\text { and Manheim } \\
\text { (1962) }\end{array}$ \\
\hline $\begin{array}{l}\text { Pierre shale (U.S. } \\
\text { western states) }\end{array}$ & - & $\begin{array}{l}1200 \\
(2000-200)\end{array}$ & $\begin{array}{l}400 \\
(700-150)\end{array}$ & V̂ine (1966) \\
\hline $\begin{array}{l}\text { Red Sea } \\
\text { Pleistocene shales }\end{array}$ & 3.3 & $\begin{array}{l}600 \\
(1500-70)\end{array}$ & $\begin{array}{l}120 \\
(500-10)\end{array}$ & This volume \\
\hline $\begin{array}{l}\text { U. Cretaceous } \\
\text { shales, Kansas }\end{array}$ & 3.8 & $\begin{array}{l}350 \\
(500-200)\end{array}$ & $\begin{array}{l}24 \\
(50-10)\end{array}$ & Vine (1966) \\
\hline Average shale & 0.88 & 130 & 2.6 & $\begin{array}{l}\text { Vine (1966) } \\
\text { Clarke (1924, } \\
\text { cited in Vine, } \\
1966)\end{array}$ \\
\hline
\end{tabular}

Figure 1 shows the distribution of $\mathrm{V}$ and Mo in black shale bands throughout Sites $225,227,228$, and 229 . One may see immediately the thinness and multiple distribution of these bands, which extend from the early-middle Pliocene to the late Pleistocene. Within Miocene evaporitic strata, nearly all shale and claystones are dark and contain significant organic matter; however, these shales only rarely contain concentrations of $\mathrm{V}$ and Mo comparable to those of younger sediments, even when the latter are strongly diluted with calcium carbonate. The concentration and distribution of the Mo-V-rich sediments apparently does not indicate stratigraphic continuity or any significant lateral zonation. Some bands are only a few centimeters wide. If the rates of deposition of the dark bands are comparable to those of the post-Miocene sediments in general, the zones rich in organic material represent periods of a few hundred years duration. In areas of less rapid accumulation than Site 229 within the central rift system, bands rich in organic material have been noted in sediments in piston cores (Manheim, in press); that is, in still younger deposits.

The mean composition of all dark, organic sediments analyzed from Sites 225,227 , and 228 is summarized in Tables 1 and 2 and in Figure 2. One may note that in pre-Miocene strata changes in composition are relatively insignificant, except that vanadium and possibly nickel are most abundant in Pleistocene and Late Pliocene strata. This includes such transition elements as $\mathrm{Ti}, \mathrm{Mn}, \mathrm{Cr}$, and $\mathrm{Co}$, suggesting that the type and relative quantity of noncarbonate detritus supplied to the Red Sea basin during this time was relatively constant. Their rather high concentrations relative to aluminum suggest that basaltic-gabbroic (high-mafic) detritus played a significant role among sediments introduced to Red Sea waters. Note, however, that $\mathrm{Si}$ and $\mathrm{Al}$ means may be biased to the low side by the upper detection limit of the spectrographic analyses.

Late Miocene (evaporitically associated) sediments show marked differences in composition. There is a sharp drop in $\mathrm{Ca}$, with corresponding increase in $\mathrm{Si}, \mathrm{Ti}$, and $\mathrm{Mg}$. Boron increases to levels characteristic of salt-pan clays (Harder, 1970; Valeyev et al., 1972) although boron is not necessarily enriched significantly in the associated pore fluids. This confirms the expectation that the sediments were laid down in late-stage evaporative brine bodies, regardless of the nature of fluids that may have subsequently replaced original waters of deposition.

In comparing the mean compositions of the black shales (Table 2) to world shale averages (Table 3), we note that in pre-Miocene strata Mo is enriched from 20- to 60 -fold over the average shale, whereas $\mathrm{V}, \mathrm{Mn}, \mathrm{Co}$, and $\mathrm{Cu}, \mathrm{Zn}, \mathrm{Ni}$, and $\mathrm{Fe}$ are significantly enriched in approximately decreasing order. $\mathrm{Ca}$ and $\mathrm{Sr}$ are also enriched, but these elements are attributable to the substantial carbonate component of the shales.

$\mathrm{B}$ and $\mathrm{Zr}$ are depleted in the shales with respect to average world shales.

In the late Miocene sediments $\mathrm{V}$ is no longer significantly enriched, Mo remains enriched, though much less than higher in the section, whereas B reverses its role and becomes enriched four-fold, notwithstanding the dilution of the boron-containing silicate component by calcium carbonate. Magnesium also increases substantially in the section.

The substantial increase in $\mathrm{Si} / \mathrm{Al}$ ratio noted in the evaporitic-associated shales may be related to the appreciable presence of cristobalite noted by Stoffers and Ross (this volume).

Finally, one should note that unlike $\mathrm{V}$ and $\mathrm{Mo}$ in pre-Miocene black shales, $\mathrm{Zn}$, and to a much lesser extent, $\mathrm{Cu}$, are locally and sporadically enriched. $\mathrm{Zn}$ appears to be primarily enriched in the form of sphalerite and was so found in bands and impregnations in the shattered anhydrite-shale breccias in the lowermost parts of Site 228 (Core 39). Its enrichment depends on a combination of physicochemical factors including fluid migration, heat gradients, and the presence of $\mathrm{H}_{2} \mathrm{~S}$, that cause local post-depositional precipitation. In contrast, $\mathrm{V}$ and Mo appear to be closely associated with uptake on organic matter or organic-matter-linked sulfides during or shortly after deposition of the sediment and are relatively immobile thereafter. Numerous authors (Hodgson, 1965, and references cited) have pointed out that porphyrins derived from degradation of plant matter (whether of terrestrial or phytoplankton origin) have a high affinity for vanadium and hold it tenaciously even under oxidizing conditions.

Mo is deposited by two major mechanisms, a reducing mode and an oxidic uptake with iron and manganese oxides as in deep ocean ferromanganese concretions. Since we are here speaking of organic and often pyrite-rich sediments, the former mode is pertinent. Ordinary shales have only very small detrital concentrations of Mo (about $2 \mathrm{ppm}$ ). Mo is strongly taken up (coprecipitated) by fine-grained iron sulfides (Korolev, 1958). Since Mo in seawater is present only in quantities of about $10 \mu \mathrm{g} / 1$, and presumably far less in oxygen-free pore fluids, molybdate being the stable mobile species, post-depositional diagenetic enrichment during burial is limited. Significant molybdenum enrichments are thus generally associated with stagnant water bodies, in which sulfide-containing sediments at the sediment-water interface can extract Mo from relatively large volumes of bottom water. For example, pre-Miocene black shales show a mean of $77 \mathrm{ppm}$ Mo, or approximately 


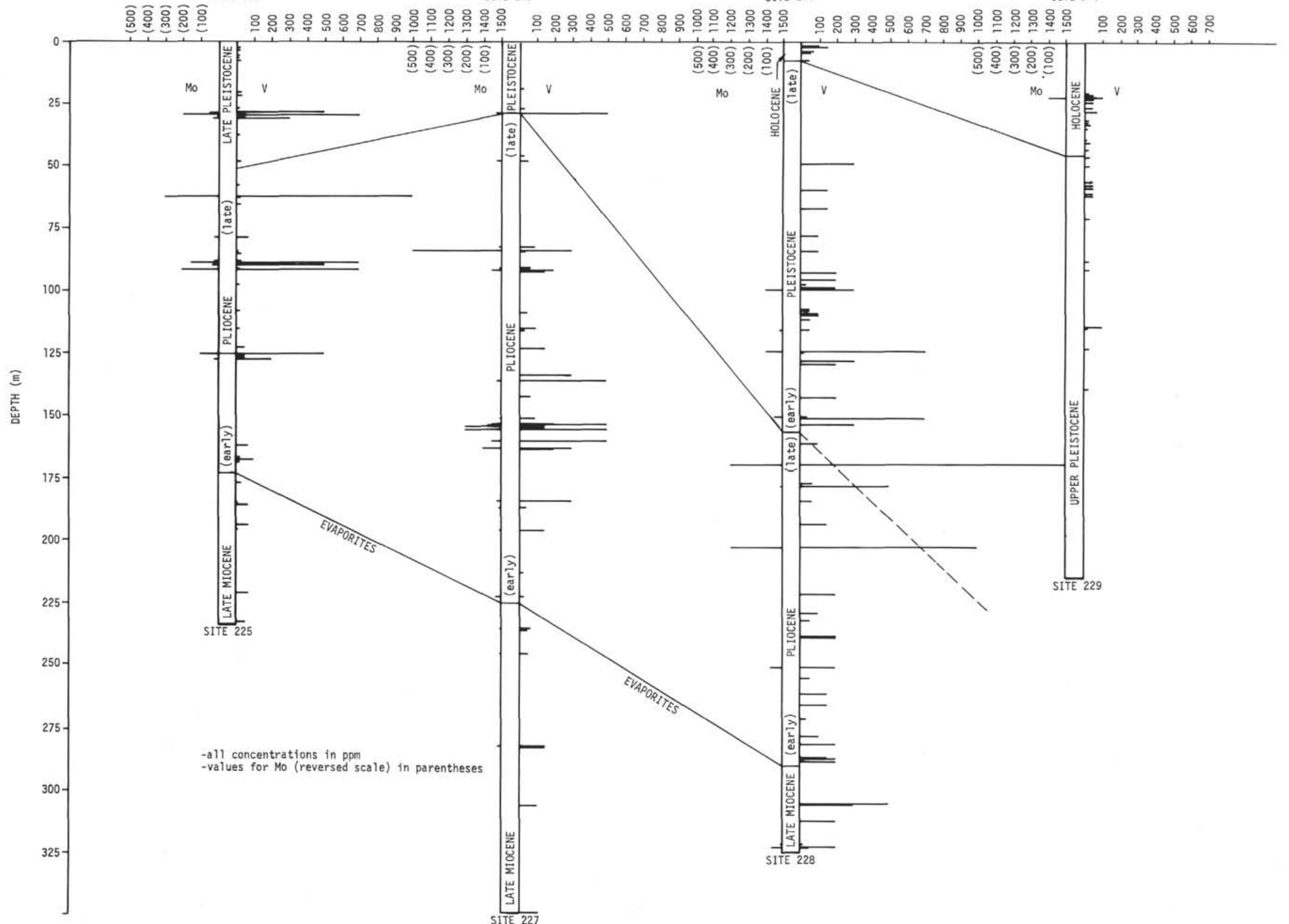


TABLE 1

Spectrochemical Analyses of (Calcareous) Black Shales by Site and Stratigraphic Horizon

\begin{tabular}{|c|c|c|c|c|c|c|c|c|c|c|c|c|c|c|c|c|c|c|c|c|c|c|}
\hline \multirow[b]{3}{*}{ Element } & \multicolumn{8}{|c|}{ Site 225} & \multicolumn{6}{|c|}{ Site 227} & \multicolumn{8}{|c|}{ Site 228} \\
\hline & \multicolumn{2}{|c|}{$\begin{array}{c}\text { L. } \\
\text { Pleistocene }\end{array}$} & \multicolumn{2}{|c|}{$\begin{array}{c}\text { E. } \\
\text { Pliocene }\end{array}$} & \multicolumn{2}{|l|}{$\begin{array}{c}\text { E. } \\
\text { Pliocene }\end{array}$} & \multicolumn{2}{|l|}{$\begin{array}{c}\text { L. } \\
\text { Miocene }\end{array}$} & \multicolumn{2}{|c|}{$\begin{array}{c}\text { L. } \\
\text { Pliocene }\end{array}$} & \multicolumn{2}{|l|}{$\begin{array}{c}\text { E. } \\
\text { Pliocene }\end{array}$} & \multicolumn{2}{|l|}{$\begin{array}{c}\text { L. } \\
\text { Miocene }\end{array}$} & \multicolumn{2}{|c|}{$\begin{array}{c}\text { E. } \\
\text { Pleistocene }\end{array}$} & \multicolumn{2}{|l|}{$\begin{array}{c}\text { L. } \\
\text { Pliocene }\end{array}$} & \multicolumn{2}{|l|}{$\begin{array}{c}\text { E. } \\
\text { Pliocene }\end{array}$} & \multicolumn{2}{|l|}{$\begin{array}{c}\text { L. } \\
\text { Miocene }\end{array}$} \\
\hline & $0-52 \mathrm{~m}$ & $N^{\mathrm{a}}$ & $52-115 \mathrm{~m}$ & $N$ & $115-173 \mathrm{~m}$ & $N$ & $173-227 \mathrm{~m}$ & $N$ & $8-65 \mathrm{~m}$ & $N$ & $65-225 \mathrm{~m}$ & $N$ & $225-239 \mathrm{~m}$ & $N$ & $51-155 \mathrm{~m}$ & $N$ & $155-273 \mathrm{~m}$ & $N$ & $273-291 \mathrm{~m}$ & $N$ & $291-325 \mathrm{~m}$ & $N$ \\
\hline $\mathrm{Si}(\%)$ & 10.7 & 3 & 12.2 & 4 & 9.5 & 2 & 22.5 & 4 & 15 & 1 & 14.0 & 12 & 24 & 5 & 12.6 & 1 & 14.6 & 7 & 25 & 3 & 19.8 & 9 \\
\hline Al (\%) & 5.0 & 3 & 4.8 & 4 & 5.0 & 2 & 5.0 & 4 & 5 & 1 & 4.8 & 12 & 3.6 & 5 & 5 & 1 & 4.7 & 7 & 5 & 3 & 4.3 & 9 \\
\hline $\mathrm{Fe}(\%)$ & 3.7 & 3 & 4.0 & 4 & 6.0 & 2 & 5.0 & 4 & 5 & 1 & 5.9 & 12 & 5.1 & 5 & 5 & 1 & 6.4 & 7 & 8 & 3 & 8.4 & 9 \\
\hline $\mathrm{Mg}(\%)$ & 1.8 & 3 & 1.8 & 4 & $1 ; 5$ & 2 & 6.2 & 4 & 5 & 1 & 2.1 & 12 & 3.3 & 5 & 1.5 & 1 & 1.6 & 7 & 1.8 & 3 & 4.1 & 9 \\
\hline $\mathrm{Ca}(\%)$ & 16.7 & 3 & 20.0 & 4 & 20.0 & 2 & 3.2 & 4 & 20 & 1 & 14.5 & 12 & 2.6 & 5 & 15 & 1 & 10.7 & 7 & 1.2 & 3 & 6.3 & 9 \\
\hline $\mathrm{Ti}(\%)$ & 0.27 & 3 & 0.28 & 4 & 0.25 & 2 & 0.4 & 4 & 0.5 & 1 & 0.31 & 12 & 0.29 & 5 & 0.2 & 1 & 0.39 & 7 & 0.7 & 3 & 0.5 & 9 \\
\hline $\mathrm{Mn}(\%)$ & 0.15 & 3 & 0.14 & 4 & 0.2 & 2 & 0.24 & 4 & 0.5 & 1 & 0.16 & 12 & 0.12 & 5 & 0.5 & 1 & 0.45 & 7 & 0.02 & 3 & 0.9 & 9 \\
\hline $\mathrm{Ag}(\mathrm{ppm})$ & 0.23 & 3 & $<0.1$ & 4 & $<0.1$ & 2 & $<0.1$ & 4 & $<0.1$ & 1 & 0.21 & 12 & $<1$ & 5 & $<1$ & 1 & $<1$ & 7 & $<0.1$ & 3 & $<0.1$ & 9 \\
\hline As (ppm) & 15 & 1 & 10 & 2 & - & - & $<5$ & 1 & 5 & 1 & 6 & 3 & $<5$ & 2 & $<5$ & 1 & $<5$ & 1 & $<5$ & 2 & $<5$ & 2 \\
\hline B (ppm) & 20 & 3 & 22 & 4 & 10 & 2 & 367 & 4 & 20 & 1 & 20 & 1 & 400 & 5 & 30 & 1 & 31 & 7 & 57 & 2 & 390 & 9 \\
\hline $\mathrm{Ba}(\mathrm{ppm})$ & 533 & 3 & 800 & 4 & 600 & 2 & 125 & 4 & 200 & 1 & 164 & 12 & 84 & 5 & 700 & 1 & 686 & 7 & 500 & 3 & 329 & 9 \\
\hline $\mathrm{Cd}(\mathrm{ppm})$ & - & - & - & - & - & - & - & - & - & - & - & - & - & - & - & - & - & - & - & - & $<25$ & 2 \\
\hline Co (ppm) & 30 & 3 & 16 & 4 & 20 & 2 & 66 & 4 & 200 & 1 & 27 & 12 & 20 & 5 & 50 & 1 & 34 & - & 43 & 3 & 18 & 9 \\
\hline $\mathrm{Cr}(\mathrm{ppm})$ & 90 & 3 & 72 & 4 & 70 & 2 & 92 & 4 & 100 & 1 & 101 & 12 & 68 & 5 & 70 & 1 & 129 & 7 & 183 & 3 & 117 & 9 \\
\hline $\mathrm{Cu}(\mathrm{ppm})$ & 73 & 3 & 55 & 4 & 85 & 2 & 175 & 4 & 700 & 1 & 99 & 12 & 164 & 5 & 70 & 1 & 104 & 7 & 117 & 3 & 146 & 9 \\
\hline $\mathrm{Mo}(\mathrm{ppm})$ & 93 & 3 & 170 & 4 & 60 & 2 & 4 & 4 & 30 & 1 & 93 & 12 & 8 & 5 & 150 & 1 & 99 & 7 & $<2$ & 3 & 24 & 9 \\
\hline $\mathrm{Ni}(\mathrm{ppm})$ & 116 & 3 & 97 & 4 & 85 & 2 & 97 & 4 & 300 & 1 & 117 & & 66 & 5 & 300 & 1 & 124 & 7 & 150 & 3 & 86 & 9 \\
\hline $\mathrm{Pb}(\mathrm{ppm})$ & 10 & 3 & 8 & 4 & 8 & 2 & 6 & 4 & 15 & 1 & 10.0 & 12 & $<5$ & 5 & 20 & 1 & 16 & 7 & 8 & 3 & 57 & 9 \\
\hline $\mathrm{Sn}(\mathrm{ppm})$ & $<3$ & 3 & $<3$ & 4 & $<3$ & 2 & $<3$ & 4 & $<3$ & 1 & $>3$ & 12 & $<3$ & 5 & $<3$ & 1 & $<3$ & 1 & $<3$ & 3 & $<3$ & 9 \\
\hline $\mathrm{Sr}$ (ppm) & 1170 & 3 & 1000 & 4 & 850 & 2 & 100 & 4 & 1000 & 1 & 858 & 12 & 220 & 5 & 1000 & 1 & 1000 & 7 & 150 & 3 & 1320 & 9 \\
\hline $\mathrm{V}(\mathrm{ppm})$ & 500 & 3 & 725 & 4 & 200 & 2 & 65 & 4 & 500 & 1 & 289 & 12 & 200 & 5 & 700 & 1 & 514 & 7 & 183 & 3 & 197 & 9 \\
\hline $\mathrm{Zn}(\mathrm{ppm})$ & 104 & 2 & 77 & 4 & 50 & 1 & 205 & 4 & $<400$ & 1 & $<100$ & 6 & 188 & 4 & 92 & 2 & 186 & 5 & 134 & 4 & 572 & 6 \\
\hline $\mathrm{Zr}(\mathrm{ppm})$ & 26 & 3 & 21 & 4 & 25 & 2 & 85 & 4 & 50 & 1 & 32 & & 33 & 5 & 50 & 1 & 60 & 7 & 233 & 3 & 98 & 9 \\
\hline
\end{tabular}

$\mathrm{a}_{N}=$ number of analyses. 
TABLE 2

Mean Values, Sites 225, 227, 228

\begin{tabular}{l|cc|cc|cc|cc}
\hline Element & Pleistocene & $N^{\mathrm{a}}$ & L. Pliocene & $N$ & E. Pliocene & $N$ & L. Miocene & $N$ \\
\hline $\mathrm{Si}(\%)$ & 11.6 & 4 & 13.9 & 12 & 16.2 & 17 & 22.1 & 18 \\
$\mathrm{Al}(\%)$ & 5.0 & 4 & 4.8 & 12 & 4.9 & 17 & 4.3 & 18 \\
$\mathrm{Fe}(\%)$ & 4.4 & 4 & 5.1 & 12 & 6.6 & 17 & 6.2 & 18 \\
$\mathrm{Ti}(\%)$ & 0.24 & 4 & 0.39 & 12 & 0.42 & 17 & 0.40 & 18 \\
$\mathrm{Ca}(\%)$ & 15.9 & 4 & 16.9 & 12 & 11.9 & 17 & 4.0 & 18 \\
$\mathrm{Mg}(\%)$ & 1.7 & 4 & 2.8 & 12 & 1.8 & 17 & 4.5 & 18 \\
$\mathrm{Mn}(\%)$ & 0.32 & 4 & 0.36 & 12 & 0.13 & 17 & 0.42 & 18 \\
$\mathrm{~Pb}(\mathrm{ppm})$ & 15 & 4 & 13 & 12 & 8.6 & 17 & 23 & 18 \\
$\mathrm{Ag}(\mathrm{ppm})$ & 0.16 & 4 & $<0.1$ & 12 & 0.14 & 17 & $<0.1$ & 18 \\
$\mathrm{Cu}(\mathrm{ppm})$ & 71 & 4 & 286 & 12 & 100 & 17 & 162 & 18 \\
$\mathrm{Zn}(\mathrm{ppm})$ & 98 & 4 & 221 & 12 & 94 & 11 & 321 & 14 \\
$\mathrm{Sn}(\mathrm{ppm})$ & $<3$ & 4 & $<3$ & 6 & $<3$ & 17 & $<3$ & \\
$\mathrm{Cd}(\mathrm{ppm})$ & - & & - & & - & & - & \\
$\mathrm{Mo}(\mathrm{ppm})$ & 121 & 4 & 99 & 12 & 52 & 17 & 12 & 18 \\
$\mathrm{Ni}(\mathrm{ppm})$ & 208 & 4 & 173 & 12 & 117 & 17 & 83 & 18 \\
$\mathrm{Co}(\mathrm{ppm})$ & 40 & 4 & 83 & 12 & 30 & 17 & 35 & 18 \\
$\mathrm{~V}$ (ppm) & 600 & 4 & 579 & 12 & 224 & 17 & 120 & 18 \\
$\mathrm{Ba}(\mathrm{ppm})$ & 616 & 4 & 562 & 12 & 421 & 17 & 179 & 18 \\
$\mathrm{Sr}(\mathrm{ppm})$ & 1083 & 4 & 1000 & 12 & 619 & 17 & 545 & 18 \\
$\mathrm{~B}$ (ppm) & 25 & 4 & 24 & 12 & 29 & 16 & 385 & 18 \\
$\mathrm{As}$ (ppm) & $<10$ & 2 & 6 & 4 & $<6$ & 5 & $<5$ & 5 \\
$\mathrm{Zr}$ (ppm) & 38 & 4 & 44 & 12 & 97 & 17 & 72 & 18 \\
$\mathrm{Cr}$ (ppm) & 80 & 4 & 100 & 12 & 118 & 17 & 92 & 18 \\
& & & & & & & & \\
\hline
\end{tabular}

${ }^{\mathrm{a}} N=$ Number of analyses.

TABLE 3

Ratio of Black Shale Components to World Shale Average (Vinogradov, 1967)

\begin{tabular}{|c|c|c|c|c|c|}
\hline Element & $\begin{array}{c}\text { World Shale } \\
\text { Average } \\
(\%)\end{array}$ & Pleistocene & L. Pliocene & E. Pliocene & L. Miocene \\
\hline $\mathrm{Si}(\%)$ & 24.0 & 0.48 & 0.58 & 0.68 & 0.92 \\
\hline $\mathrm{Al}(\%)$ & 9.52 & 0.53 & 0.50 & 0.51 & 0.45 \\
\hline $\mathrm{Fe}(\%)$ & 3.32 & 1.3 & 1.5 & 2.0 & 1.8 \\
\hline $\mathrm{Ti}(\%)$ & 0.43 & 0.56 & 0.91 & 0.98 & 0.93 \\
\hline $\mathrm{Ca}(\%)$ & 2.50 & 6.4 & 6.8 & 4.8 & 1.60 \\
\hline $\mathrm{Mg}(\%)$ & 1.39 & 1.2 & 2.0 & 1.3 & 3.2 \\
\hline $\operatorname{Mn}(\%)$ & 0.070 & 4.6 & 5.1 & 1.9 & 6.0 \\
\hline $\mathrm{Pb}(\mathrm{ppm})$ & 20 & 0.7 & 0.7 & 0.4 & 1.1 \\
\hline $\mathrm{Ag}(\mathrm{ppm})$ & - & - & - & - & - \\
\hline $\mathrm{Cu}(\mathrm{ppm})$ & 57 & 1.3 & 5.0 & 1.8 & 2.8 \\
\hline $\mathrm{Zn}(\mathrm{ppm})$ & 80 & 1.2 & (2.8) & $(1.2)$ & 4.0 \\
\hline $\mathrm{Mo}(\mathrm{ppm})$ & 2 & 61 & 50 & (26) & (6.1) \\
\hline $\mathrm{Ni}(\mathrm{ppm})$ & 95 & 2.2 & 1.8 & 1.2 & 0.9 \\
\hline Co (ppm) & 20 & 2.0 & 4.2 & 1.5 & 1.7 \\
\hline $\mathrm{V}(\mathrm{ppm})$ & 130 & 4.6 & 4.4 & 1.7 & 0.9 \\
\hline $\mathrm{Ba}(\mathrm{ppm})$ & 800 & 0.8 & 0.7 & 0.5 & 0.2 \\
\hline $\mathrm{Sr}(\mathrm{ppm})$ & 450 & 2.4 & 2.2 & 1.4 & 1.2 \\
\hline B (ppm) & 100 & 0.25 & 0.24 & 0.29 & 3.9 \\
\hline As (ppm) & - & - & - & - & - \\
\hline $\mathrm{Zr}$ (ppm) & 200 & 0.19 & 0.21 & 0.48 & 0.36 \\
\hline $\mathrm{Cr}(\mathrm{ppm})$ & 100 & 0.8 & 1.0 & 1.2 & 0.9 \\
\hline
\end{tabular}

$75 \mathrm{ppm}$ Mo corrected for possible detrital contributions. At a concentration of $10 \mu \mathrm{g} / \mathrm{l} \mathrm{Mo}$, each gram of dry sediment contains the equivalent of all the Mo in 7.5 liters of water. Considering that probably efficiency of uptake from bottom waters is far lower than 100 percent, many tens or perhaps hundreds of liters of water must sweep past bottom sediments to provide the necessary Mo. One can conclude that the dark bands of sediment represent times of extensive surface productivity and bottom water stagnation, resulting in oxygen-free bottom sediments, and that the reducing zone includes the sediment-water interface. Incorporation of Mo directly in organic matter as a metal-organic complex would require similar environmental conditions. 


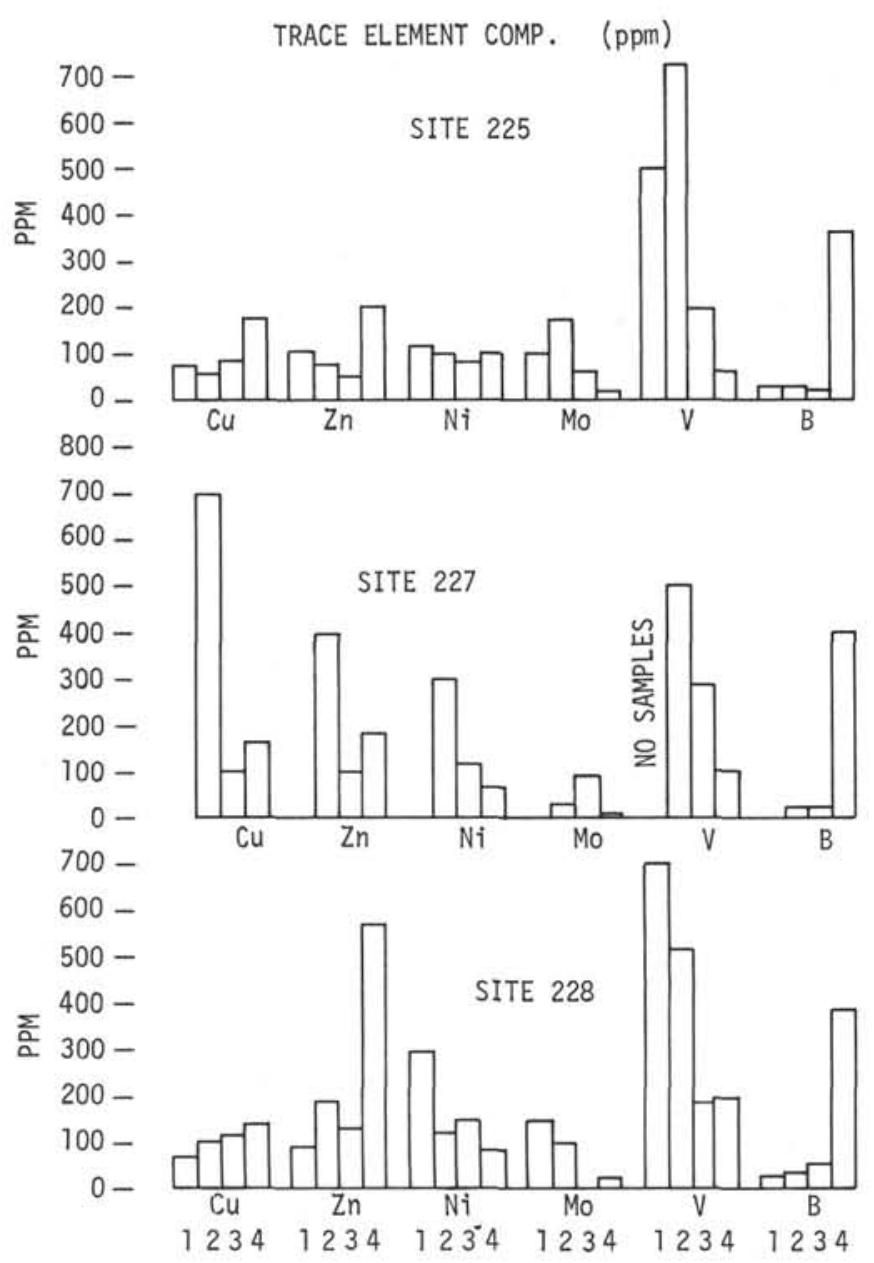

Figure 2. Concentration of $\mathrm{Cu}, \mathrm{Zn}, \mathrm{Ni}, \mathrm{Mo}, \mathrm{V}$, and $\mathrm{B}$ in black shales from Sites 225, 227, and 228, Red Sea. Asterisk indicates value determined by single, realtively high-metal content sample. Numbers denote: (1) Pleistocene; (2) late Pliocene; (3) early Pliocene; (4) late Miocene (evaporite series).

According to Pratsch (1973, oral communication), black shales are also widespread in the Pleistocene of drill holes on the Ethiopian continental margin of the Red Sea. We may presume that these are analogous to those in our drill cores. Therefore, the black shales appear to be characteristics of the Red Sea Neogene in general.

\section{Non-Black Shales and Carbonates}

Mean composition of non-black shale sediments is given by site and stratigraphic interval in Table 4 , utilizing the spectrographic analyses. Results of both rapid rock ("chemical") and spectrographic analyses are summarized for black shale and non-black shale samples in Table 5 . There may be some overestimation of $\mathrm{Fe}$ by the spectrochemical method, this being primarily designed for trace constituents, and less free from systematic effects of matrix for major constituents.

Enrichments in the black shales of V, Mo, and transition metals are marked in pre-Miocene strata. In the evaporite-associated shales, copper and zinc are enriched. However, the mean values for $\mathrm{Cu}$ and $\mathrm{Zn}$ are far less impressive than local enrichments, reaching as much as 5 percent in sphalerite-rich zones at Site 228.

The general composition of non-black shale sediments is consistent with an admixture of basaltic-gabbroic and some less mafic (granitic) detritus, as described by Coleman (this volume) with biogenic carbonate material. The mafic influence is suggested by relatively high concentrations of $\mathrm{Ni}, \mathrm{Co}, \mathrm{Cr}, \mathrm{Ti}$, and $\mathrm{Mg}$, but low concentrations of elements more prominent in granitic (acidic) rocks such as $\mathrm{Zr}$ and $\mathrm{Pb}$. $\mathrm{Mg}$ concentrations may also be enhanced by some detrital dolomite (Stoffers and Ross, this volume) and unusual concentrations of palygorskite, a hydrous magnesium silicate believed by Stoffers and Ross (this volume) to be derived in large part from transport from the Arabian continent rather than by in situ alteration of volcanic glass. Still another source of $\mathrm{Mg}$ is magnesium calcite. In the lowermost portion of Site 227 magnesite is reported. This unusual mineral is probably related to the late-stage evaporitic minerals (tachyhydrite-bischofite) and magnesium-rich brines associated with them that are found at this site (Manheim et al., this volume).

\section{Pyrite}

Means of composition of semiquantitative analyses of small pyrite grains and aggregates picked by the paleontologists (especially R. Fleisher) are given in Table 6. The compositions are rather typical for sedimentary pyrites except with regard to the unusually low lead concentrations. One might note that low lead concentrations are also characteristic of sphalerite-rich separates noted previously (Manheim and Siems, this volume), and the Red Sea sediments generally. This appears to be partly related to low lead content in detrital materials entering the Red Sea, it being a rather low lead province in general. The major constituents such as $\mathrm{Ca}, \mathrm{Ti}$, and others are associated with impurities attached to the pyrite grains.

A significant difference in composition of pyrites, associated with color, was observed. Yellow, brassy pyrites contain low arsenic concentrations, whereas silver-white pyrites, hinting at arsenopyrite, contain large concentrations (over $1000 \mathrm{ppm} \mathrm{As}$ ). The arsenic traces were distributed in an erratic manner, however, and have not been linked to any given stratigraphic interval or sediment type.

\section{Lithified Carbonates}

As discussed in Milliman et al. (1969) and references cited, lithified layers containing both aragonite and high magnesian calcite are common in surficial sediments of the Red Sea. The drill cores reveal that aragonite and high magnesian calcite occurrences are frequent throughout the Pleistocene of Sites 225, 228, and 229, but decline with depth. Deepest aragonites recorded in the X-ray data are at 160 meters at Site 227 (early Pliocene). The chemical data (Table 7) reflect presence of both inorganically precipitated aragonite and magnesian calcite in the lithified crusts from Pleistocene and Pliocene sections. Taken as a whole, however, Sites 225, 227, and 228 contain only small proportions of aragonite (approximately 5 percent or less of total carbonate). Since the mean $\mathrm{Sr}$ for all samples from these sites is usually below $1000 \mathrm{ppm}$, lower than that 
TABLE 4

Spectrochemical Analyses of Non-black Shale Sediments by Site and Stratigraphic Horizon

\begin{tabular}{|c|c|c|c|c|c|c|c|c|c|c|c|c|c|c|}
\hline \multirow[b]{3}{*}{ Element } & \multicolumn{8}{|c|}{ Site 225} & \multicolumn{6}{|c|}{ Site 227} \\
\hline & \multicolumn{2}{|c|}{ Pleistocene } & \multicolumn{2}{|c|}{ L. Pliocene } & \multicolumn{2}{|c|}{ E. Pliocene } & \multicolumn{2}{|c|}{ L. Miocene } & \multicolumn{2}{|c|}{ Pleistocene } & \multicolumn{2}{|c|}{ L. Pliocene } & \multicolumn{2}{|c|}{ E. Pliocene } \\
\hline & $0-52 \mathrm{~m}$ & $N^{\mathrm{a}}$ & $52-115 \mathrm{~m}$ & $N$ & $115-173 \mathrm{~m}$ & $N$ & $173-227 \mathrm{~m}$ & $N$ & $0-28 \mathrm{~m}$ & $N$ & $28-65 \mathrm{~m}$ & $N$ & $65-225 \mathrm{~m}$ & $N$ \\
\hline $\mathrm{Si}(\%)^{\mathrm{b}}$ & 13 & 9 & 13 & 13 & 17 & 7 & 54 & 3 & 15 & 2 & 14 & 4 & 16 & 16 \\
\hline $\mathrm{Al}(\%)^{\mathrm{b}}$ & 4.3 & 9 & 4.7 & 13 & 5.4 & 7 & 3.8 & 3 & 5.0 & 2 & 5 & 4 & 5.0 & 16 \\
\hline $\mathrm{Fe}(\%)$ & 4.9 & 9 & 3.8 & 13 & 5.3 & 7 & 2.4 & 3 & 3.5 & 2 & 4.2 & 4 & 4.6 & 16 \\
\hline $\mathrm{Mg}(\%)$ & 4.6 & 9 & 4.0 & 13 & 4.0 & 7 & 4.0 & 3 & 6.0 & 2 & 4.8 & 4 & 2.2 & 16 \\
\hline $\mathrm{Ca}(\%)$ & 18 & 9 & 18 & 13 & 16 & 7 & 13 & 3 & 20 & 2 & 20 & 4 & 14 & 16 \\
\hline $\mathrm{Ti}(\%)$ & 0.3 & 9 & 0.35 & 13 & 0.43 & 7 & 0.26 & 3 & 0.4 & 2 & 0.4 & 4 & 0.42 & 16 \\
\hline $\operatorname{Mn}(\%)$ & 0.21 & 9 & 0.22 & 13 & 0.2 & 7 & 0.2 & 3 & 0.4 & 2 & 0.38 & 4 & 0.24 & 16 \\
\hline $\mathrm{Ag}(\mathrm{ppm})$ & $<0.1$ & 9 & $<0.1$ & 13 & $<0.1$ & 7 & $<0.1$ & 3 & $<0.1$ & 2 & $<0.1$ & 4 & $<0.1$ & 16 \\
\hline As (ppm) & - & - & - & - & - & - & - & - & $<5$ & 2 & - & - & - & - \\
\hline B (ppm) & 20 & 9 & 12 & 13 & 24 & 7 & 150 & 3 & 20 & 2 & 11 & 4 & 23 & 16 \\
\hline $\mathrm{Ba}(\mathrm{ppm})$ & 68 & 9 & 65 & 13 & 96 & 7 & 87 & 3 & 100 & 2 & 85 & 4 & 219 & 16 \\
\hline $\mathrm{Cd}(\mathrm{ppm})$ & - & - & - & - & - & - & - & - & - & - & - & - & - & - \\
\hline Co (ppm) & 12 & 9 & 12 & 13 & 30 & 7 & 90 & 3 & 15 & 2 & 25 & 4 & 21 & 16 \\
\hline $\mathrm{Cr}(\mathrm{ppm})$ & 77 & 9 & 81 & 13 & 96 & 7 & 83 & 3 & 100 & 2 & 92 & 4 & 170 & 16 \\
\hline $\mathrm{Cu}(\mathrm{ppm})$ & 32 & 9 & 39 & 13 & 86 & 7 & 47 & 3 & 60 & 2 & 52 & 4 & 78 & 16 \\
\hline $\mathrm{Mo}(\mathrm{ppm})$ & 2.7 & 9 & 27 & 13 & $<2$ & 7 & 4 & 3 & $<2$ & 2 & 6 & 4 & 14 & 16 \\
\hline $\mathrm{Ni}(\mathrm{ppm})$ & 69 & 9 & 70 & 13 & 96 & 7 & 41 & 3 & 75 & 2 & 90 & 4 & 102 & 16 \\
\hline $\mathrm{Pb}(\mathrm{ppm})$ & 8 & 9 & 6 & 13 & 7 & 7 & 6 & 3 & 7.5 & 2 & 12 & 4 & $<50$ & 16 \\
\hline $\mathrm{Sn}(\mathrm{ppm})$ & $<3$ & 9 & $<3$ & 13 & $<3$ & 7 & $<3$ & 3 & $<3$ & 2 & $<3$ & 4 & $<3$ & 16 \\
\hline $\mathrm{Sr}(\mathrm{ppm})$ & 1290 & 9 & 800 & 13 & 450 & 7 & 450 & 3 & 1000 & 2 & 670 & 4 & 710 & 16 \\
\hline $\mathrm{V}(\mathrm{ppm})$ & 29 & 9 & 42 & 13 & 51 & 7 & 37 & 3 & 30 & 2 & 32 & 4 & 110 & 16 \\
\hline $\mathrm{Zn}(\mathrm{ppm})$ & 7 & 9 & - & - & - & - & $<50$ & 1 & - & - & - & - & - & - \\
\hline $\mathrm{Zr}(\mathrm{ppm})$ & 53 & 9 & 42 & 13 & 51 & 7 & 40 & 3 & 50 & 2 & 42 & 4 & 51 & 16 \\
\hline
\end{tabular}

$\mathrm{a}_{N}=$ number of analyses.

biased on core side by upper detection limits.

estimated to characterize fresh planktonic foraminifera or coccoliths (about 1500 ppm according to Manheim et al., 1971, and references cited), the dominant contribution of $\mathrm{Sr}$ to pore fluid may be made by the recrystallization of calcite to lower-Sr forms, rather than the higher-Sr, but less abundant aragonite $(0.9 \% \mathrm{Sr})$.

The aragonitic lithified layers in piston cores have been related to episodes of higher than normal salinity at 11,000 to 20,000; 50,000; and 70,000 years (Milliman et al., 1969, and references cited). In principle, if these layers could be preserved during burial to depths on the order of 200 meters below the sea floor, with temperatures of about $35^{\circ} \mathrm{C}$ or above, aragonite rather than low magnesian calcite ought to be the stable phase. However, increasing temperature, ionic strength of solutions, and $\mathrm{Mg}$ concentrations in the pore fluids (the latter of evaporitic origin) promote dolomite formation at the expense of aragonite. For this reason, aragonite is presumably absent in the lower levels of Sites 225, 227 and 228.

Mean Sr content of samples from Site 229 is about 2000 ppm, considerably higher than at the other sites. This site also contains appreciably more aragonite in its carbonate fraction. Although much of this aragonite is attributable to low-Sr pteropod tests, presumably a significant proportion is also due to post-depositional growth of inorganic (high-Sr) aragonite. The high proportion of $\mathrm{Sr}$ (about 100 $\mathrm{ppm}$ ) in the pore fluid may be due to recrystallization of both aragonite and biogenic calcite.

\section{Evaporitic Rocks and Mineral Parageneses: Possible Unrecovered Evaporite Minerals}

Some partial analyses of anhydrite and halite, minerals of overwhelming dominance in evaporite suites, are given in Table 8. However, Stoffers and Kühn (this volume) show that a potassium-bearing phase, judged to be polyhalite from petrographic observations, is frequently present in amounts over 1 percent (11 out of 29 halite samples). $\mathrm{Br}$ and $\mathrm{K}$ values, the latter recalculated from Stoffers and Kühns's polyhalite values, are plotted for Site 227 in Figure 3 , along with data from two samples analyzed by the U.S. Geological Survey laboratories. The only sample from the same lithologic interval (at $228 \mathrm{~m}$ ) shows excellent agreement between the laboratories' results.

Stoffers and Kühn discuss the significance of $\mathrm{K}, \mathrm{Br}$, and $\mathrm{Sr}$ data in some detail, arriving at the following chief conclusions:

1) Using $\mathrm{Br} / \mathrm{NaCl}$ as an indicator of the degree of evaporation of an original seawater parent brine, values range from 0.004 to 0.017 , corresponding to the boundary of the anhydrite and halite precipitation zones and the halite/polyhalite zones, are obtained. It is recognized that polyhalite $\left(\mathrm{K}_{2} \mathrm{Ca}_{2} \mathrm{Mg}\left(\mathrm{SO}_{4}\right)_{4} \cdot 2 \mathrm{H}_{2} \mathrm{O}\right.$ is not normally a primary evaporite mineral.

2) Bromine values have also been used by Kühn (1953) to estimate depth of water in the evaporite depositional 
TABLE 4 - Continued

\begin{tabular}{|c|c|c|c|c|c|c|c|c|c|c|c|c|c|c|}
\hline \multirow[b]{3}{*}{ Element } & \multicolumn{10}{|c|}{ Site 228} & \multicolumn{4}{|c|}{ Site 229} \\
\hline & \multicolumn{2}{|c|}{ Holocene } & \multicolumn{2}{|c|}{ Pleistocene } & \multicolumn{2}{|c|}{ L. Pliocene } & \multicolumn{2}{|c|}{ E. Pliocene } & \multicolumn{2}{|c|}{ L. Miocene } & \multicolumn{2}{|l|}{ Holocene } & \multicolumn{2}{|c|}{ Pleistocene } \\
\hline & $0-7 \mathrm{~m}$ & $N^{\mathrm{a}}$ & $7-155 \mathrm{~m}$ & $N$ & $155-273 \mathrm{~m}$ & $N$ & $273-291 \mathrm{~m}$ & $N$ & $291-325 \mathrm{~m}$ & $N$ & $0-45 \mathrm{~m}$ & $N$ & $45-210 \mathrm{~m}$ & $N$ \\
\hline $\mathrm{Si}(\%)^{\mathrm{b}}$ & 17 & 5 & 19 & 21 & 19 & 9 & 22 & 2 & 19 & 9 & 14 & 18 & 15 & 10 \\
\hline $\mathrm{Al}(\%)^{\mathrm{b}}$ & 5.0 & 5 & 4.9 & 21 & 4.8 & 9 & $>5$ & 2 & 4.8 & 9 & 4.9 & 18 & 4.6 & 10 \\
\hline $\mathrm{Fe}(\%)$ & 6.8 & 5 & 7.6 & 21 & 6.1 & 9 & 7 & 2 & 8.3 & 9 & 3.9 & 18 & 3.4 & 10 \\
\hline $\mathrm{Mg}(\%)$ & 16 & 5 & 3.6 & 21 & 2.2 & 9 & 4 & 2 & 6.0 & 9 & 5.0 & 18 & 3.9 & 10 \\
\hline $\mathrm{Ca}(\%)$ & 11 & 5 & 15 & 21 & 10 & 9 & 4.2 & 2 & 5.7 & 9 & 18 & 18 & 17 & 10 \\
\hline $\mathrm{Ti}(\%)$ & & 5 & 0.52 & 21 & 0.56 & 9 & 0.6 & 2 & 0.53 & 9 & 0.47 & 18 & 0.42 & 10 \\
\hline $\operatorname{Mn}(\%)$ & & 5 & 0.36 & 21 & 0.20 & 9 & 0.2 & 2 & 1.3 & 9 & 0.06 & 18 & 0.10 & 10 \\
\hline $\mathrm{Ag}(\mathrm{ppm})$ & $<0.1$ & 5 & $<0.1$ & 21 & $<0.1$ & 9 & $<0.1$ & 2 & $<0.1$ & & $<0.1$ & 18 & $<0.2$ & 10 \\
\hline As (ppm) & - & - & $<10$ & 21 & - & - & - & - & - & - & - & - & - & - \\
\hline B (ppm) & 18 & 5 & 24 & 21 & 12 & 9 & 30 & 2 & 490 & 9 & 19 & 18 & 16 & 10 \\
\hline $\mathrm{Ba}(\mathrm{ppm})$ & 230 & 5 & 250 & 21 & 247 & 9 & 350 & 2 & 400 & 9 & 84 & 18 & 85 & 10 \\
\hline $\mathrm{Cd}(\mathrm{ppm})$ & - & - & - & - & - & - & - & - & - & - & - & - & - & - \\
\hline $\mathrm{Co}(\mathrm{ppm})$ & 18 & 5 & 25 & 21 & 25 & 9 & 22 & 2 & 18 & 9 & 12 & 18 & 11 & 10 \\
\hline $\mathrm{Cr}(\mathrm{ppm})$ & 140 & 5 & 149 & 21 & 139 & 9 & 175 & 2 & 113 & 9 & 179 & 18 & 163 & 10 \\
\hline $\mathrm{Cu}(\mathrm{ppm})$ & 70 & 5 & 67 & 21 & 65 & 9 & 85 & 2 & 157 & 9 & 25 & 18 & 41 & 10 \\
\hline $\mathrm{Mo}(\mathrm{ppm})$ & $<2$ & 5 & 12 & 21 & $<2$ & 9 & (2) & 2 & 3 & 9 & $<7.8$ & 18 & $<2$ & 10 \\
\hline $\mathrm{Ni}(\mathrm{ppm})$ & 88 & 5 & 104 & 21 & 83 & 9 & 110 & 2 & 72 & 9 & 103 & 18 & 91 & 10 \\
\hline $\mathrm{Pb}(\mathrm{ppm})$ & 10 & 5 & 8 & 21 & 6.1 & 9 & $<5$ & 2 & 54 & 9 & 6 & 18 & 8 & 10 \\
\hline $\mathrm{Sn}(\mathrm{ppm})$ & $<3$ & 5 & $<3$ & 21 & $<3$ & 9 & $<3$ & 2 & $<3$ & 9 & 3 & 18 & $<3$ & 10 \\
\hline $\mathrm{Sr}(\mathrm{ppm})$ & 840 & 5 & 1220 & 21 & 530 & 9 & 150 & 2 & 480 & 9 & 2040 & 18 & 1970 & 10 \\
\hline $\mathrm{V}(\mathrm{ppm})$ & 84 & 5 & 169 & 21 & 117 & 9 & 150 & 2 & 133 & 9 & 46 & 18 & 56 & 10 \\
\hline $\mathrm{Zn}(\mathrm{ppm})$ & - & - & - & - & - & - & - & - & $<500$ & 9 & - & - & - & - \\
\hline $\mathrm{Zr}(\mathrm{ppm})$ & 104 & 5 & 138 & 21 & 116 & 9 & 150 & 2 & 100 & & 190 & 18 & 144 & 10 \\
\hline
\end{tabular}

$\mathrm{a}_{N}=$ number of analyses.

biased on core side by upper detection limits.

basin. Using this technique for halite sequences at Sites 225 and 228 , a water depth of only a few meters was deduced.

3) Dirty gray halites have abundant fluid inclusions in contrast to clear white halites. The latter are presumed to be recrystallization products. However, the clear halite tended to have "enigmatically" higher bromine concentrations.

4) $\mathrm{Sr} / \mathrm{Ca} \cdot 1000$ values associated with anhydrites vary from 3.5 to 25 . Values between 1 and 3 are held to denote isomorphous $\mathrm{Sr}-\mathrm{Ca}$ replacements. Discrete strontium minerals are found at values greater than 7, whereas only celestite should occur in anhydrite for values above 20 . Primary anhydrite ought to have greater $\mathrm{Sr}$ content $(0.23)$ than gypsum (0.23), according to Usdowski, cited in Stoffers and Kühn (this volume). About half of the anhydrites showed $\mathrm{Sr}$ content greater than 0.23 . Based on this, as well as the anhydrites' massive habit, the authors concluded most anhydrite to be primary, rather than recrystallized gypsum.

5) Although Stoffers and Kühn hold to a shallow origin of the observed evaporites, they suggest that earlier evaporites might have been deposited in deep water according to the model of Schmalz (1969); i.e., the latest deposits are only the culmination of salt buildup in a deep basin. The waters were presumably supplied from the Mediterranean during "waterfall" episodes between intermittent desiccation of both basins. This would be an extension of the concept of Hsü et al. (1973) for the Mediterranean Sea.

Before commenting here and in succeeding sections on Stoffers' and Kühn's concept, one should recognize that the recovered evaporites and associated rocks represent only about one half or less of total penetrated intervals; moreover, the halites had been reduced to about half of wireline core diameter by leaching during core retrieval. Thus, it is quite possible that other, more soluble evaporitic phases were lost in the coring process. Polyhalites would be retained since this sulfate mineral is more akin to anhydrite than halite in its solubility.

Fortunately, interstitial waters in shales associated with the evaporitic rocks yield data from which one can estimate the nature of original evaporites at depth. This is because diffusivity measurements discussed later indicate that in the course of geologic time, pore fluid within associated shales should be in virtually complete equilibrium with evaporites some meters away. However, the shales have very poor bulk permeability, so that only their outer layers (including the margins of breaks and cracks) will be contaminated by drilling fluid during core recovery. By removing these outer layers prior to squeezing, contamination can be minimized.

At Site 225 the interstitial fluids in the deepest sample show marked increases in $\mathrm{Mg}, \mathrm{K}$, and $\mathrm{SO}_{4}$, relationships that could signal approach to equilibrium with a mineral assemblage of halite, anhydrite, and polyhalite. However, Site 227 shows a quite different picture. Here the non- $\mathrm{NaCl}$ component of the brine is dominated by $\mathrm{Mg}$ - $\mathrm{Ca}$ chlorides, 
TABLE 5

Chemical ("Rapid Rock") and Spectrochemical Averages for Major Sediment Types for Red Sea Strata, Excluding Hot Brine Deposits

\begin{tabular}{|c|c|c|c|c|c|c|c|c|}
\hline \multirow[b]{3}{*}{ Element } & \multicolumn{4}{|c|}{ Black Shales } & \multicolumn{4}{|c|}{ Nonblack Shales } \\
\hline & \multicolumn{2}{|c|}{ Pre-Miocene } & \multicolumn{2}{|c|}{ Miocene } & \multicolumn{2}{|c|}{ Pre-Miocene } & \multicolumn{2}{|c|}{ Miocene } \\
\hline & $\begin{array}{l}N=33 \\
\text { Spectro. }\end{array}$ & $\begin{array}{l}N=3 \\
\text { Chem. }\end{array}$ & $\begin{array}{c}N=18 \\
\text { Spectro. }\end{array}$ & $\begin{array}{l}N=1 \\
\text { Chem. }\end{array}$ & $\begin{array}{l}N=116 \\
\text { Spectro. }\end{array}$ & $\begin{array}{l}N=22 \\
\text { Chem. }\end{array}$ & $\begin{array}{c}N=12 \\
\text { Spectro. }\end{array}$ & $\begin{array}{l}N=1 \\
\text { Chem. }\end{array}$ \\
\hline $\mathrm{SiO}_{2}$ & 31.7 & 43.5 & 47.3 & 46.5 & 34.0 & 29.4 & 59.5 & 39.2 \\
\hline $\mathrm{Si}$ & 14.8 & 20.3 & 22.1 & 21.7 & 15.9 & 13.7 & 27.8 & 18.3 \\
\hline $\mathrm{Al}_{2} \mathrm{O}_{3}$ & 6.8 & 13.2 & 6.5 & 10.6 & 6.74 & 8.9 & 6.32 & 8.6 \\
\hline & 4.87 & 9.5 & 4.3 & 7.63 & 4.85 & 6.4 & 4.55 & 6.2 \\
\hline $\mathrm{Fe}_{2} \mathrm{O}_{3}$ & 8.3 & 3.8 & 8.9 & 6.80 & 7.33 & 2.9 & 9.77 & 2.6 \\
\hline & 5.8 & $4.8^{\mathrm{a}}$ & 6.2 & $7.71^{\mathrm{a}}$ & 5.13 & $3.34 \mathrm{a}$ & 6.83 & $2.75^{\mathrm{a}}$ \\
\hline $\mathrm{TiO}_{2}$ & 0.65 & 0.76 & 0.67 & 0.64 & 0.73 & 0.58 & 0.77 & 0.43 \\
\hline $\mathrm{Ti}$ & 0.39 & 0.46 & 0.40 & 0.38 & 0.44 & 0.35 & 0.46 & 0.26 \\
\hline $\mathrm{CaO}$ & 19.9 & 6.50 & 5.60 & 1.1 & 21.8 & 22.6 & 10.5 & 9.6 \\
\hline $\mathrm{Ca}$ & 14.2 & 4.65 & 4.0 & 0.79 & 15.6 & 16.2 & 7.53 & 6.86 \\
\hline $\mathrm{MgO}$ & 3.56 & 5.33 & 7.46 & 8.2 & 7.15 & 3.89 & 9.12 & 8.7 \\
\hline $\mathrm{Mg}$ & 2.15 & 3.21 & 4.5 & 4.95 & 4.31 & 2.35 & 5.50 & 5.25 \\
\hline $\mathrm{MnO}$ & 0.31 & 0.11 & 0.54 & 0.21 & 0.28 & 0.14 & 1.33 & 0.08 \\
\hline $\mathrm{Mn}$ & 0.24 & 0.085 & 0.42 & 0.16 & 0.22 & 0.11 & 1.03 & 0.062 \\
\hline $\mathrm{SrO}$ & & 0.12 & & 0.01 & & 0.083 & & 0.02 \\
\hline $\mathrm{Sr}$ & & 0.010 & 0.00 & 0.008 & & 0.070 & & 0.017 \\
\hline $\mathrm{Na}_{2} \mathrm{O}$ & & 3.01 & & 2.29 & & 1.45 & & 2.59 \\
\hline $\mathrm{Na}$ & & 2.23 & & 1.70 & & 1.08 & & 1.92 \\
\hline $\mathrm{K}_{2} \mathrm{O}$ & & 1.93 & & 1.81 & & 1.20 & & 1.40 \\
\hline $\mathrm{K}$ & & 1.60 & & 1.50 & & 1.00 & & 1.16 \\
\hline $\mathrm{P}_{2} \mathrm{O}_{5}$ & & 0.24 & & 0.17 & & 0.26 & & 0.37 \\
\hline & & 0.10 & & 0.074 & & 0.11 & & 0.16 \\
\hline $\begin{array}{l}\text { Organic } \\
\text { Carbon }\end{array}$ & & $3.3^{b}$ & & $1.7 \mathrm{c}$ & & & & \\
\hline $\mathrm{Pb}$ & 11 & 6 & 23 & & 7 & 5 & 42 & 5 \\
\hline $\mathrm{Ag}$ & $<0.13$ & $\mathrm{NA}^{\mathrm{d}}$ & $<0.1$ & NA & $<0.1$ & NA & $<0.1$ & NA \\
\hline $\mathrm{Cu}$ & 164 & 132 & 161 & - & 54 & 49 & 129 & 76 \\
\hline $\mathrm{Zn}$ & 124 & 104 & 321 & - & - & 43 & - & 51 \\
\hline Sn & $<3$ & NA & $<3$ & NA & (3) & NA & (3) & NA \\
\hline $\mathrm{Cd}$ & - & NA & - & NA & - & NA & - & NA \\
\hline Mo & 77 & NA & 12 & - & (9) & 11 & - & (2) \\
\hline $\mathrm{Ni}$ & 149 & NA & 83 & - & 92 & 57 & 64 & 20 \\
\hline Co & 50 & NA & 35 & NA & 18 & NA & 16 & $\mathrm{NA}$ \\
\hline V & 398 & NA & 120 & - & 84 & 107 & 109 & 9 \\
\hline $\mathrm{Ba}$ & 496 & NA & 179 & NA & 153 & NA & 320 & NA \\
\hline $\mathrm{Sr}$ & 814 & NA & 545 & NA & 114 & NA & 470 & NA \\
\hline B & 26 & 53 & 385 & - & 19 & 41 & 404 & 280 \\
\hline As & 7 & NA & $<5$ & NA & - & NA & - & NA \\
\hline $\mathrm{Zr}$ & 70 & NA & 72 & NA & 89 & NA & 85 & NA \\
\hline $\mathrm{Cr}$ & 107 & NA & 92 & NA & 112 & NA & 105 & NA \\
\hline
\end{tabular}

Note: $N$ refers to number of samples for major constituents. Values are in percent dry weight for major constituents and ppm for trace elements (shown as element form only). Note that semiquantitative analysis method is primarily directed toward trace elements and is less reliable for major constituents. In some cases, $\mathrm{Al}$ and $\mathrm{Si}$ spectrochemical means may be biased on the low side because of the upper limit of technique. Organic carbon determined at DSDP laboratory, Scripps Institution of Oceanography, La Jolla (G. W. Bode).

${ }^{\mathrm{a}}$ Total iron.

${ }^{\mathrm{b}}$ Mean of 20 analyses.

${ }^{\mathrm{c}}$ Mean of 6 analyses.

$\mathrm{d}_{\mathrm{NA}}=$ not analyzed.

suggesting a bischofite $\left(\mathrm{MgCl}_{2} \cdot 6 \mathrm{H}_{2} \mathrm{O}\right)$-tachyhydrite $\left(\mathrm{Mg}_{2} \mathrm{CaCl}_{6} \cdot 12 \mathrm{H}_{2} \mathrm{O}\right)$ mineral assemblage. Table 9 summarizes the non- $\mathrm{NaCl}$ components in Site 225 and 227 brines, together with corresponding components of comparative minerals possibly present in the evaporitic rocks. Site 228 had not yet reached the halite-stage rocks and the interstitial waters here are not in equilibium with them, though they rapidly approach saturation with $\mathrm{NaCl}$ 
TABLE 6

Pyrite Samples, Sites 225-229

\begin{tabular}{l|c|c|c|c|c|c}
\hline Element & \multicolumn{2}{|c|}{ Pleistocene } & $N$ & \multicolumn{2}{l|}{ Late Pliocene } & \multicolumn{2}{|c}{ Early Pliocene } & $N$ \\
\hline $\mathrm{Si}(\%)$ & 4.3 & 3 & 5.3 & 6 & 8.0 & 6 \\
$\mathrm{Al}(\%)$ & 1.1 & 3 & 1.5 & 6 & 2.7 & 6 \\
$\mathrm{Fe}(\%)$ & $>20$ & 3 & $>20$ & 6 & $>20$ & 6 \\
$\mathrm{Ti}(\%)$ & 0.012 & 3 & 0.04 & 6 & 0.035 & 6 \\
$\mathrm{Ca}(\%)$ & 1.7 & 3 & 3.0 & 6 & 4.3 & 6 \\
$\mathrm{Mg}(\%)$ & 0.02 & 3 & 0.076 & 6 & 1.2 & 6 \\
$\mathrm{Mn}(\%)$ & 0.032 & 3 & 0.067 & 6 & 0.055 & 6 \\
$\mathrm{~Pb}(\mathrm{ppm})$ & $(5)$ & 3 & $(5)$ & 6 & 13 & 5 \\
$\mathrm{Ag}(\mathrm{ppm})$ & $(0.1)$ & 3 & $(0.1)$ & 6 & 0.17 & 6 \\
$\mathrm{Cu}(\mathrm{ppm})$ & 60 & 3 & 125 & 6 & 157 & 6 \\
$\mathrm{Zn}(\mathrm{ppm})$ & $(140)$ & 2 & - & - & 417 & 2 \\
$\mathrm{Sn}(\mathrm{ppm})$ & $(3)$ & 3 & $(3)$ & 6 & $(3)$ & 6 \\
$\mathrm{Cd}(\mathrm{ppm})$ & - & - & - & - & - & - \\
$\mathrm{Mo}(\mathrm{ppm})$ & 333 & 3 & 185 & 6 & 103 & 6 \\
$\mathrm{Ni}(\mathrm{ppm})$ & 273 & 3 & 293 & 6 & 250 & 6 \\
$\mathrm{Co}(\mathrm{ppm})$ & 41.7 & 3 & 88 & 6 & 41 & 6 \\
$\mathrm{~V}(\mathrm{ppm})$ & 11.3 & 3 & 13 & 6 & 13 & 6 \\
$\mathrm{Ba}(\mathrm{ppm})$ & 10 & 3 & $(11)$ & 6 & $(10)$ & 6 \\
$\mathrm{Sr}(\mathrm{ppm})$ & 16.8 & 3 & 83 & 6 & 67 & 6 \\
$\mathrm{~B}$ (ppm) & 33 & 3 & 19 & 6 & 18 & 6 \\
$\mathrm{As}(\mathrm{ppm})$ & $(1000)$ & 1 & $(150)$ & 6 & $(360)$ & 6 \\
$\mathrm{Zr}(\mathrm{ppm})$ & 10 & 3 & 5.8 & 6 & $(5.8)$ & 6 \\
$\mathrm{Cr}(\mathrm{ppm})$ & 7.3 & 3 & 41 & 6 & 8.3 & 6 \\
& & &
\end{tabular}

with depth.

Another mechanism is suggested by laboratory experiments of Raup (1973, oral communication) which are consistent with suggestions of D'Ans (1961), field data of Holser (1966), and particularly pertinent to the polyhalite-tachyhydrite problem: this is the reaction of gypsum or anhydrite with tachyhydrite-bischofite-related solutions to form polyhalite and calcium chloride at temperatures greater than room temperature.

$$
\begin{aligned}
& \mathrm{CaMg}_{2} \mathrm{Cl}_{6} \cdot 12 \mathrm{H}_{2} \mathrm{O}+4 \mathrm{KCl}+8 \mathrm{CaSO}_{4} \rightarrow \\
& \text { (tachyhydrite) } \\
& 2 \mathrm{~K}_{2} \mathrm{Ca}_{2} \mathrm{Mg}\left(\mathrm{SO}_{4}\right)_{4}\left(\mathrm{H}_{2} \mathrm{O}\right)_{2}+5 \mathrm{CaCl}_{2}+4 \mathrm{H}_{2} \mathrm{O}
\end{aligned}
$$

The available evidence suggests a qualitative scheme for the development of mineral parageneses found at Sites 225 and 227. The evaporitic rocks in both areas were laid down under conditions that irregularly permitted accumulation of minor late-stage evaporites, such as carnallite, sylvite, tachyhydrite, and bischofite, as well as other phases, together with concentrated chloride-rich brines. Possibly some secondary polyhalite was already formed at this stage. However, additional polyhalite may have formed from reaction between interstitial brine and anhydrite at a somewhat later, post-burial stage, when temperatures increased further. Recrystallization of earlier formed halites and crystallization of polyhalites formed the clearer, later bands, whereas the early formed halite may be represented by the gray phase described by Stoffers and Kühn (this volume) as containing abundant fluid inclusions and chevron and hopper structures. This relationship would

\begin{tabular}{|c|c|c|}
\hline \multirow[b]{2}{*}{ Element } & \multicolumn{2}{|c|}{ Pre-Miocene } \\
\hline & $\begin{array}{c}N=9 \\
\text { Spectro. }\end{array}$ & $\begin{array}{l}N=2 \\
\text { Chem. }\end{array}$ \\
\hline $\mathrm{SiO}_{2}$ & 19.5 & 22.6 \\
\hline $\mathrm{Si}$ & 9.13 & 10.56 \\
\hline $\mathrm{Al}_{2} \mathrm{O}_{3}$ & 5.22 & 6.70 \\
\hline Al & 3.76 & 4.82 \\
\hline $\mathrm{Fe}_{2} \mathrm{O}_{3}$ & 2.09 & 2.25 \\
\hline $\mathrm{Fe}$ & 1.46 & $2.10^{\mathrm{a}}$ \\
\hline $\mathrm{TiO}_{2}$ & 0.43 & 0.59 \\
\hline $\mathrm{Ti}$ & 0.26 & 0.35 \\
\hline $\mathrm{CaO}$ & 26.4 & 27.8 \\
\hline $\mathrm{Ca}$ & 18.9 & 19.9 \\
\hline $\mathrm{MgO}$ & 5.37 & 5.0 \\
\hline $\mathrm{Mg}$ & 3.24 & 3.02 \\
\hline $\mathrm{MnO}$ & 0.084 & 0.12 \\
\hline $\mathrm{Mn}$ & 0.065 & 0.093 \\
\hline $\mathrm{Na}_{2} \mathrm{O}$ & & 0.69 \\
\hline $\mathrm{Na}$ & & 0.51 \\
\hline $\mathrm{K}_{2} \mathrm{O}$ & & 0.87 \\
\hline K & & 0.72 \\
\hline $\mathrm{P}_{2} \mathrm{O}_{5}$ & & 0.48 \\
\hline$P$ & & 0.21 \\
\hline $\mathrm{Pb}(\mathrm{ppm})$ & $(<5)$ & \\
\hline $\mathrm{Ag}$ (ppm) & $<0.1$ & \\
\hline $\mathrm{Cu}(\mathrm{ppm})$ & 16 & \\
\hline $\mathrm{Zn}(\mathrm{ppm})$ & $<60$ & \\
\hline Sn (ppm) & $<3$ & \\
\hline Mo (ppm) & $<2$ & \\
\hline $\mathrm{Ni}(\mathrm{ppm})$ & 35 & \\
\hline Co (ppm) & 7 & \\
\hline $\mathrm{U}(\mathrm{ppm})$ & 26 & \\
\hline $\mathrm{Ba}(\mathrm{ppm})$ & 30 & \\
\hline $\mathrm{Sr}(\mathrm{ppm})$ & 3410 & \\
\hline B (ppm) & 13 & \\
\hline As (ppm) & - & \\
\hline $\mathrm{Zr}(\mathrm{ppm})$ & 37 & \\
\hline $\mathrm{Cr}$ (ppm) & 86 & \\
\hline
\end{tabular}
explain the higher $\mathrm{Br}$ concentrations in the clear halite
TABLE 7

Composition of Lithified Carbonates

layers, since these may have formed in equilibrium with a brine partly enriched with late-stage components due to both mother liquors and dissolution of solid phases. Since both carnallites and tachyhydrites can contain more than $4000 \mathrm{ppm} \mathrm{Br}$ in their structures, dissolution of such minerals could yield very high $\mathrm{Br}$ (and also $\mathrm{B}, \mathrm{Li}$, etc.) concentrations. A considerable part of the originally trapped interstitial solutes may have diffused away during the immediate post-burial stage of the evaporites, so that the interstitial waters now remaining represent a closer approach to equilibrium with the evaporite minerals. 
TABLE 8

Analyses of Evaporitic Rocks

\begin{tabular}{|c|c|c|c|c|}
\hline \multicolumn{4}{|c|}{ Anhydrites } & \\
\hline $\begin{array}{c}\text { Major Constituent } \\
(\%)\end{array}$ & $\begin{array}{l}225-24-1 \\
135 / 140 \\
\end{array}$ & $227-37-2$ & $228-37-2$ & \\
\hline $\begin{array}{l}\mathrm{CaO} \\
\mathrm{SrO} \\
\mathrm{MgO} \\
\mathrm{K}_{2} \mathrm{O} \\
\mathrm{SO}_{3} \\
\mathrm{SUM}^{2}\end{array}$ & $\begin{array}{c}(38.9) \\
0.13 \\
0.53 \\
0.05 \\
55.5 \\
95.1\end{array}$ & $\begin{array}{c}(38.9) \\
0.15 \\
4.5 \\
0.04 \\
55.5 \\
97.1\end{array}$ & $\begin{array}{c}(39.2) \\
0.20 \\
0.53 \\
0.02 \\
55.9 \\
95.6\end{array}$ & \\
\hline \multicolumn{5}{|l|}{ Traces (ppm) } \\
\hline $\begin{array}{l}\mathrm{Fe} \\
\mathrm{Mn} \\
\mathrm{Ti} \\
\mathrm{B} \\
\mathrm{Bi} \\
\mathrm{U}\end{array}$ & $\begin{array}{c}-- \\
-- \\
-- \\
<1 \\
<10 \\
0.6\end{array}$ & $\begin{array}{c}<20 \\
20 \\
50 \\
34 \\
<10 \\
0.8\end{array}$ & $\begin{array}{c}-- \\
-- \\
-- \\
<1 \\
<10 \\
0.6\end{array}$ & \\
\hline \multicolumn{5}{|c|}{ Halite Rock } \\
\hline $\begin{array}{l}\text { Major Constituent } \\
(\%)\end{array}$ & $\begin{array}{c}225 \\
\text { " } 200 \mathrm{~m} "\end{array}$ & $227-27-2$ & $227-31, \mathrm{CC}$ & $227-93-4$ \\
\hline $\begin{array}{l}\mathrm{CaO}^{\mathrm{a}} \\
\mathrm{SrO} \\
\mathrm{MgO} \\
\mathrm{K}_{2} \mathrm{O} \\
\mathrm{SO}_{3}\end{array}$ & $\begin{array}{l}(3.8) \\
0.02 \\
0.08 \\
0.04 \\
4.6\end{array}$ & $\begin{array}{c}(1.1) \\
0.01 \\
0.03 \\
0.01 \\
1.34\end{array}$ & $\begin{array}{c}\text { (I.04) } \\
<0.01 \\
2.8 \\
0.63 \\
1.25\end{array}$ & $\begin{array}{l}(0.47) \\
0.02 \\
0.04 \\
0.57\end{array}$ \\
\hline \multicolumn{5}{|l|}{ Traces (ppm) } \\
\hline $\begin{array}{l}\mathrm{B} \\
\mathrm{Br} \\
\mathrm{U}\end{array}$ & $\begin{array}{r}160 \\
<10 \\
0.3\end{array}$ & $\begin{array}{c}160 \\
33 \\
0.4\end{array}$ & $\begin{array}{l}200 \\
110 \\
0.4\end{array}$ & $\begin{array}{c}280 \\
44 \\
0.4\end{array}$ \\
\hline
\end{tabular}

Note: $\mathrm{Fe}, \mathrm{Mn}$, and $\mathrm{Ti}$ from semiquantitative spectrochemical analyses. Other components by U. S. Geological Survey, Analytical Laboratories, Washington, D. C.

${ }^{\mathrm{a}} \mathrm{Ca}$ corresponding stoichiometrically to $\mathrm{SO}_{4}$; does not include other (e.g., carbonate) forms.

According to Manheim et al. (this volume) the dried interstitial salt in the bottom of Site 227 (350 meters) would correspond to 66 percent halite, 32 percent tachyhydrite having a composition of $\mathrm{Ca}_{0.6} \mathrm{Mg}_{2.4}$ $\mathrm{Cl}_{6} \cdot 12 \mathrm{H}_{2} \mathrm{O}, \quad 1.5$ percent carnallite, and 0.5 percent anhydrite. Although tachyhydrite is a hitherto rarely found mineral, there is evidence that members of the $\mathrm{MgCl}_{2}-\mathrm{CaCl}_{2}-\mathrm{H}_{2} \mathrm{O}$ mineral series may be far more important than commonly realized. Highlighting this concept is the recent discovery of bedded primary tachyhydrite aggregating more than 100 meters thickness in Lower Cretaceous evaporite deposits on the east coast of Brazil (Wardlaw, 1972). One should note that tachyhydrite is not stable at room temperature and is extremely hygroscopic $\left(\mathrm{CaCl}_{2}\right.$ being commonly used as a desiccant). Thus, in the Sergipe (Brazil) deposits some cores imperfectly coated with paraffin were found later to have complete liquified (Raup, 1973, oral communication). Therefore, many evaporite deposits, especially those associated with high- $\mathrm{CaCl}_{2}$ brines, may have contained minor admixtures of tachyhydrite at depth (and under

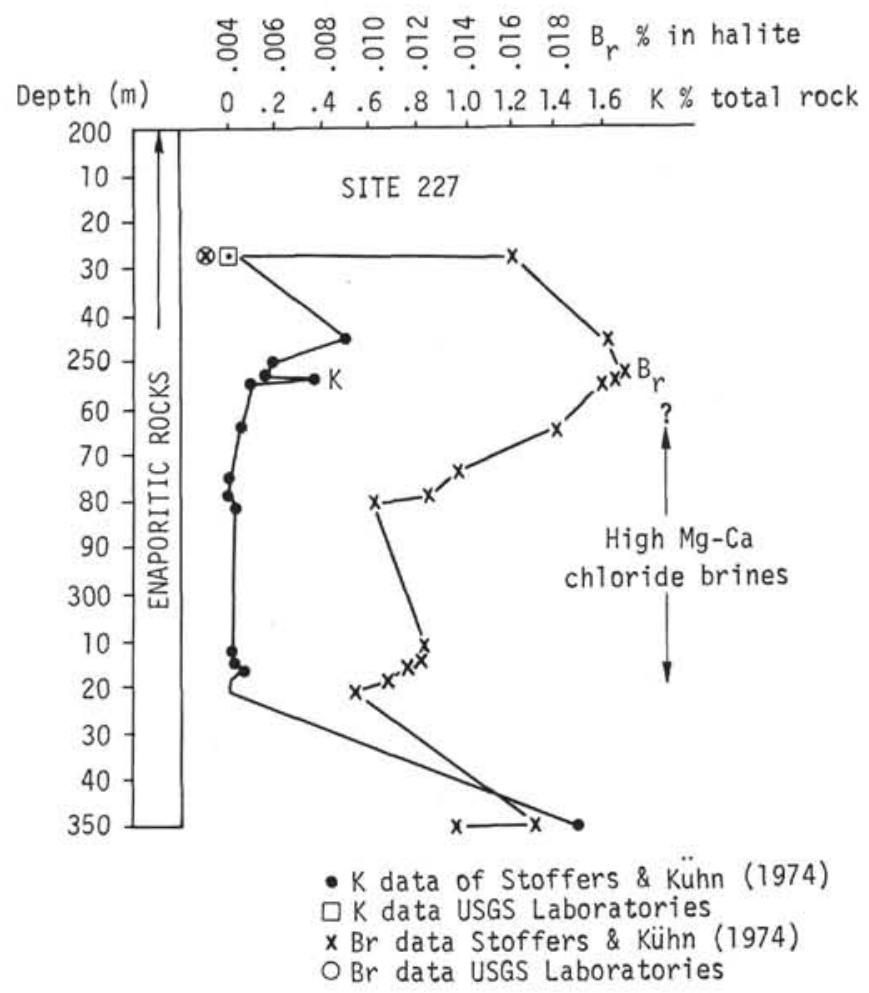

Figure 3. Distribution of $\mathrm{Br}$ and $\mathrm{K}$ with depth in Site 227.

TABLE 9

Mole Percent of Components In Evaporite Minerals and Residual Interstitial Brine Salts (Excluding Halite)

\begin{tabular}{lllllc}
\hline \multicolumn{1}{c}{ Mineral } & $\mathrm{K}$ & $\mathrm{Mg}$ & $\mathrm{Ca}$ & $\mathrm{Ch}$ & $\mathrm{SO}_{4}$ \\
\hline Polyhalite $\left(\mathrm{K}_{2} \mathrm{Ca}_{2} \mathrm{Mg}\left(\mathrm{SO}_{4}\right)_{4} \cdot 2 \mathrm{H}_{2} \mathrm{O}\right)$ & 22.2 & 11.1 & 22.2 & & 44.5 \\
Carnallite $\left(\mathrm{KMgCl}_{3} \cdot 6 \mathrm{H}_{2} \mathrm{O}\right)$ & 20 & 20 & - & 60 & - \\
Bischofite $\left(\mathrm{MgCl}_{2} \cdot 6 \mathrm{H}_{2} \mathrm{O}\right)$ & - & 33.3 & - & 66.6 & - \\
Tachyhydrite $\left(\mathrm{CaMg}_{2} \mathrm{Cl}_{6} \cdot 12 \mathrm{H}_{2} \mathrm{O}\right)$ & - & 22.2 & 11.1 & 66.6 & - \\
Site 225a & 9.5 & 22.2 & 4.2 & 51.8 & 12.2 \\
Site 226 & 8.4 & 4.6 & 23.9 & 61.8 & 1.2 \\
Site 227b & 0.9 & 26.1 & 6.4 & 65.2 & 0.5 \\
Seawater & 6 & 31 & 6 & 40 & 17 \\
\hline
\end{tabular}

a 28-1(H), 212 meter depth. Sample extracted while heated to approximate in situ conditions.

b $44, \mathrm{CC}, 350$ meter depth. Sulfate estimated from equilibrium data for saturation with anhydrite at $50^{\circ} \mathrm{C}$, as indicated in Manheim et al., this volume, Table 2.

higher temperatures), which mineral was lost in the course of core recovery and manipulation.

The pathways by which dominantly calcium chloride brines are formed have been much discussed, since excesses of calcium over magnesium are much more common than the reverse. This is a serious problem, since late-stage marine brines should be expected to be depleted in calcium. Discussions of this problem, with references to other sources are offered by Zaitsev (1968) and Wardlaw (1972). 
Sources of calcium pertinent to the present case include dolomitization

$$
\mathrm{MgCl}_{2}+2 \mathrm{CaCO}_{3} \rightarrow \mathrm{MgCa}\left(\mathrm{CO}_{3}\right)_{2}+\mathrm{CaCl}_{2}
$$

ion exchange with clays, or exchange reactions with silicates

$$
\begin{aligned}
& \underset{\text { (anorthite) }}{2 \mathrm{NaCl}}+\underset{\text { (silica) }}{\mathrm{CaAl}_{2} \mathrm{Si}_{2} \mathrm{O}_{8}}+\underset{2 \mathrm{SiO}_{2}}{2 \mathrm{H}_{2} \mathrm{O}} \rightarrow \\
& \begin{array}{l}
2 \mathrm{NaAlSi} \\
\text { (analcime) }
\end{array} \\
& \text { (analcime }
\end{aligned}
$$

After burial and consolidation of the layers, the almost completely impermeable halite beds should have shielded the deeper intraevaporite units from interaction with later rocks or from appreciable fluid or ion loss.

Where late-stage evaporites are precipitated and redissolved, one might expect a great variability in trace element enrichment in the resulting liquids. Halites and polyhalites that are precipitated or recrystallized in equilibrium with such solutions could show quite extreme variations that might influence calculations using the $\mathrm{Br}$ depth and $\mathrm{Sr}$ indicators previously mentioned.

\section{Composition of Hot Brine Sediments (Site 226)}

The disturbed nature of the sediments from this site did not offer much promise of improvement over previous detailed studies of the metalliferous brines (Bischoff, 1969; Hackett and Bischoff, 1973). A general comparison of the semiquantitative analyses with previous averages is given in Table 10 .

Taking into account the experimental error, the only possibly significant difference between the presently recovered sediment and previous studies is in the

\begin{tabular}{|c|c|c|c|}
\hline & Fe-Mont. & Goeth. & Site $226(1-6 \mathrm{~m} ?)$ \\
\hline $\mathrm{SiO}_{2}$ & 24 & 24 & $15-27$ \\
\hline $\mathrm{Al}_{2} \mathrm{O}_{3}$ & 1.7 & 1.1 & 5 \\
\hline $\mathrm{Fe}_{2} \mathrm{O}_{3}$ & 35 & 49 & $20-30$ \\
\hline $\mathrm{Mn}_{3} \mathrm{O}_{4}$ & 2 & 2.8 & $0.4-1.0$ \\
\hline $\mathrm{CaO}$ & 4.8 & 3.4 & $5-22^{a}$ \\
\hline $\mathrm{ZnO}$ & 4.7 & 1.0 & 1 \\
\hline $\mathrm{CuO}$ & 0.7 & 0.5 & $0.7-1.0$ \\
\hline $\mathrm{PbO}$ & 0.1 & 0.1 & $0.7-0.5$ \\
\hline $\mathrm{AgO}$ & 0.0062 & 0.0033 & $0.003-0.007$ \\
\hline
\end{tabular}
appreciably higher $\mathrm{Pb}$ and lower $\mathrm{Mn}$ concentrations. No lead values were found in the previous studies as high as the

TABLE 10

Comparative Data for Hot Brine Sediments

Note: "Fe-Mont", and "Goeth." refer to Fe Montmorillonite and geothite facies of Bischoff (1969); Site 226 data from

Table 2 in Manheim and Siems (this volume). Values are in percent air-dry, largely brine-free, sediment.

${ }^{a}$ Reflects admixture of anhydrite:
0.5 percent registered here. However, the spectrochemical estimates were not confirmed by a sample from Site 226 (1-4) analyzed by Delevaux and Doe (this volume) and hence should be taken cautiously.

\section{Carbon and Oxygen Isotopic Composition of the Sediments}

Isotopic relationships in bulk carbonates (Lawrence, this volume) are subject to a variety of influences: individual relationships characteristic for given carbonate tests, partial equilibration with Red Sea bottom water on death of organisms, and equilibration with interstitial water and other solid phases of buried sediment. Lithified carbonates from a variety of subeuphotic environments (Milliman and Müller, in preparation) show a consistent correlation between $\delta \mathrm{C}^{13}$ and $\delta \mathrm{O}^{18}$ (line $\mathrm{A}-\mathrm{A}^{\prime}$ in Figure 4 ). It is suggested that this apparent equilibration is dominated by the nature of $\mathrm{CO}_{3}=$ ion at the time of precipitation of the calcium carbonate, rather than protracted equilibration of the solid phase with water or carbonate-water systems after sediment burial. In contrast, a scattering area roughly indicated by line B-B' shows the behavior of fresh planktonic foraminifera and coccolithophorids and many biologically formed shallow-water limestones. Still other patterns characterize volcanic or other unusual carbonates.

The isotopic data for Red Sea bulk carbonates fall clearly on the "lithified sediment" line in Figure 4, indicating substantial crystallization of the carbonates

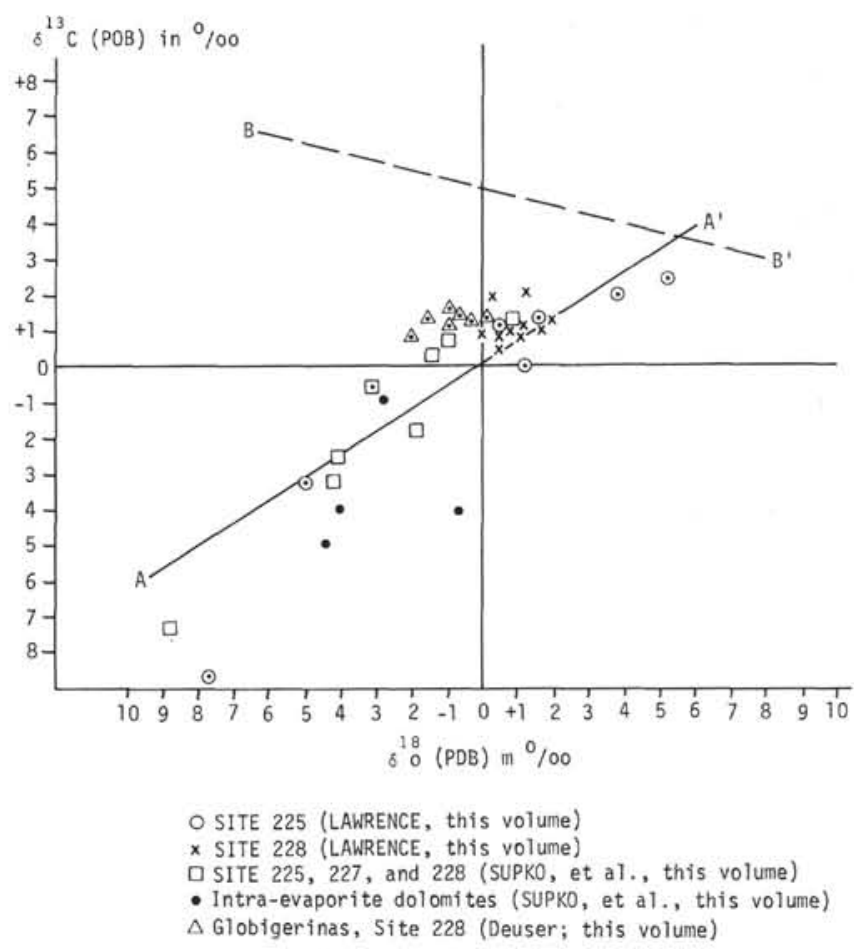

Figure 4. $\mathrm{C}^{13}$ and $\mathrm{O}^{18}$ data for carbonate sediments from Sites 225, 227, and 228, Red Sea. Line $A-A^{\prime}$ refers to trend line for subeuphotically lithified carbonates, world oceans. Line $B-B^{\prime}$ roughly indicates region of scatter for shallow water (euphotic zone) carbonates, virtually exclusively of biogenic origin. 
below the photic zone. The great spread in data reflects in part the variety of environments, both "evaporated," or otherwise heavy-isotope-enriched, and depleted (fresh water type), characterizing the Red Sea sediments.

A comparison of the oxygen isotopic data from bulk carbonates and interstitial waters shows a widening divergence toward greater depths. Both bulk carbonate and interstitial water isotopic $\left(\delta \mathrm{O}^{18}\right)$ ratios tend to become lower with depth, reflecting the meteorically influenced water input in the evaporite sequence, but the interstitial waters show the more pronounced change. Lawrence (this volume) points out the possibility that weathering of volcanic ash or igneous detritus $\left(\delta \mathrm{O}^{18}+6\right.$ to $+13 \%$ 。 SMOW) to authigenic silicates such as montmorillonite $(8018+22$ to $+28 \%$ ) could influence the isotopic composition of recrystallized carbonate. However, no general increase in $\delta \mathrm{O}^{18}$ of the bulk silicate with depth is found ( $\delta \mathrm{O}^{18}$ approximately +12 to $+18 \%$ for Site 228 ). Isotopic ratios for some intraevaporitic dolomites also showed equilibration of the carbonates with light, "meteorically influenced" waters. We may reject the concept that the enrichments in light isotopes originate by local fractionation effects (e.g., reduction of sulfate) owing to the consistent $\delta \mathrm{D}-\delta \mathrm{O}^{18}$ relationships in the pore fluids (Figures 6 and 7 and later discussion).

\section{Uranium, Lead, and Sulfur Isotopic Data}

$\mathrm{Ku}$ (this volume) points out that Red Sea sediments in general have relatively low $\mathrm{Th} / \mathrm{U}$ ratios (1.6-2.7). Uranium concentrations, except for Site 229, are comparable to those of average shales and pelagic clays $(2-3 \mathrm{ppm})$. Site 229 showed U values from 8 to $19 \mathrm{ppm}$ of the bulk sediment, or up to $60 \mathrm{ppm}$ on an assumed carbonate-free basis. Th/U ratios were only 0.13 to 0.48 . Post-depositional migration of $\mathrm{U}$ is assumed on the basis of the $\mathrm{Th}^{230} / \mathrm{U}^{234}$ data. Although radiometric dating did not prove feasible for the Site 229 materials, in spite of the rapid accumulation there, an estimate for Site 228 (Core 1, Section 1) provides a rough figure on the order of $10 \mathrm{~cm} / 10^{3}$ years, in general agreement with previous radiometric data from the area as well as paleontologic estimates.

Lead isotope data (Delevaux and Doe, this volume) generally confirm previous findings relating leads from Atlantis II deep metalliferous sediments to a mantle (possible leached volcanics) origin, and establish their affinity to ores found at Rabigh, on the Saudi Arabian coast. Similarly, lead from Site 227 (Core 20, Section 4) showed leads derived from pelagic sediments, comparable to the most radiogenic sediments from the Red Sea reported earlier.

A very important result was shown by the lead isotopic composition of the brecciated anhydrite-shale sequence (Core 39, Section 1) at Site 228. The lead-enriched sample is isotopically related to the Atlantis II and Discovery deeps metalliferous samples, and thus provides the first genetic link between metals in the known hot-brine deeps and other Red Sea sites. This point is discussed further later.

$\delta \mathrm{S}^{34}$ values of -33 to -36 from Site 227, Cores 3 and 13, are typical for $\mathrm{H}_{2} \mathrm{~S}$ and associated metal sulfides produced from reduction of sulfates by bacteria (Shanks et al., this volume) in recent marine basins. On the other hand, sulfides in heavy mineral separates from the brecciated shales and anhydrites in the bottom of Site 228 (Core 39), showed $\delta \mathrm{S}^{34}$ values ranging from -12 to $+22 \%$. The mean, $+3 \%$, is not far from the mean of the range found for hot brine sediments by Kaplan et al. (1969) and Hartmann and Nielsen (1966). The new data for Site 228 do not contradict an origin of the sulfides related to that of the hot brine deep sediments, but the exact source and mode of origin of the sulfides in both remains controversial and not fully understood.

\section{Potassium-Argon Measurements on Evaporite Associated Rocks}

Measurements of $\mathrm{Ar}^{40}$ and $\mathrm{K}$ on anhydrite from Miocene strata at Site 227 and on shale from Site 228, Core 37 , Section $1,110 \mathrm{~cm}$ were performed on whole-rock specimens. $^{2}$ The anhydrite could not be dated owing to insufficient (negligible) potassium content. The shale, from a depth of about 305 meters, provided the following data:

$$
\begin{array}{cccc}
\mathrm{K}(\%) & \mathrm{Ar}^{40}(\mathrm{ppm}) & \mathrm{Ar}^{40} / \text { Tot. Ar apparent age (m.y.) } \\
3.35 & 0.0404 & 0.700 & 162 \pm 6
\end{array}
$$

The apparent age yielded by this measurement is far too great to correspond with the real age of the horizon, which is presumably Miocene. There are two possible explanations for this anomaly. First, the very fine clay material of which the sample is chiefly constituted may be detritus from older sediments and other rocks eroded from the Sudanese mainland. Coleman (this volume) reports that heavy minerals from Plio-Pleistocene rocks at this site suggest an affinity to granitic metamorphic rocks, possibly Precambrian rocks and their weathering products distributed through the former delta region on the Sudanese continental margin near Site 228. A second possiblity is that excess argon migrating from potassic materials in deeper strata has been incorporated into the fine-grained clays at this site. Although the evidence of fluid migration is strong, the first explanation is probably to be preferred, partly because most of the indigenous clay minerals associated with the deeper Red Sea strata tend to be montmorillonite and chlorite (Stoffers and Ross, this volume) which have considerably lower $\mathrm{K}$ content than the present shale.

\section{FLUIDS AND GASES}

\section{Hot Brine Deeps}

Extensive information is available on the properties of hot brines and sediment interstitial waters from the hot brine sediments. These data and current information are compiled in Tables 11 and 12. With some exceptions, most of the interstitial water data fall within analytical or manipulative error limits of the precise data for Atlantis II and Discovery deeps brines reported by Brewer and Spencer (1969). Most variable are $\mathrm{Ca}$ and $\mathrm{SO}_{4}$ both in Brewer and Spencer's Discovery Deep samplings, as well as in interstitial water studies of Hendricks et al. (1969). These may be expected, since interstitial waters are often associated with solid anhydrite, and changes in temperature and other

\footnotetext{
${ }^{2}$ Krueger Enterprises, Inc., Geochron Laboratories Division.
} 
TABLE 11

Major Element Composition of Fluid Phases in Red Sea Sediment Hot Brine Systems

\begin{tabular}{|c|c|c|c|c|c|}
\hline Element & $\begin{array}{c}\text { Red Sea } \\
\text { Deep Water }\end{array}$ & Atlantis II Deep ${ }^{a}$ & Discovery Deep ${ }^{a}$ & $\begin{array}{l}\text { A-II Deep, } 1965 \\
\text { Interstitial Waters b }\end{array}$ & $\begin{array}{l}\text { A-II Deep, } 1972 \\
\text { Interstitial Waters }\end{array}$ \\
\hline $\mathrm{Cl}$ & 22.5 & $\begin{array}{l}156.3 \\
157.3^{d}\end{array}$ & 155.3 & $154-160$ & $157.5^{\mathrm{e}}$ \\
\hline $\mathrm{Br}$ & 0.076 & 0.128 & $0.119-0.123$ & $0.95-0.13$ & $0.10^{\mathrm{f}}$ \\
\hline $\mathrm{SO}_{4}$ & 3.14 & 0.840 & $0.75-0.70$ & $\sim 0.5$ & 0.79 \\
\hline$\leqslant \mathrm{CO}_{2}$ as $\mathrm{HCO}_{3}$ & $0.14^{\mathrm{g}}$ & $0.075-0.132^{\mathrm{g}}$ & $0.032^{h}$ & - & (alk $\mathrm{HCO}_{3}$ ) \\
\hline $\mathrm{Na}$ & 12.5 & 92.6 & $92.8-93.0$ & $93-97$ & 93.1 \\
\hline $\mathrm{K}$ & 0.45 & 1.87 & 2.15 & $2.2-2.5^{\mathrm{i}}$ & 2.10 \\
\hline $\mathrm{Ca}$ & 0.47 & 5.15 & $4.7-5.1$ & $4.7-5.7$ & 6.0 \\
\hline $\mathrm{Mg}$ & 1.49 & 0.764 & 0.81 & $0.66-0.73$ & 0.70 \\
\hline Total dissolved solids & 40.6 & 257.3 & 256.4 & - & 260.4 \\
\hline
\end{tabular}

NOTE: Red sea bottom water is estimated from normal oceanic salt composition (Culkin, 1965) adjusted to normal bottom water chlorinity for the rift valley positions as given in Miller et al. (1966). Surface water salinities vary. Atlantis II Deep chlorinity from (d) refers to sampling of 1971, whereas other value represents sampling of 1965 . Major element interstitial water data are taken chiefly from Core $84 \mathrm{~K}$ data of Hendricks et al. (1969) since their extractions were performed onboard. Some major element data (g) also available in Brooks et al. (1969), but their extractions were performed on stored cores and are accordingly less preferred. $K$ values in data of Hendricks et al. (1969) are consistently much too low and may be a typographic error or faulty calibration. All values in $\mathrm{g} / \mathrm{hg}$.

${ }^{a}$ Brewer and Spencer (1969). Shishkina and Bogoyavlenskii (1970) also agree with the authors' results.

${ }^{b}$ Hendricks et al. (1969).

CManheim et al. (this volume) mean of two samples from Site 226, SW A-II Deep: 226-1-2 and 226-1-4 (IW)

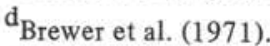

${ }^{\mathrm{e}}$ Includes $\mathrm{Br}$ and $\mathrm{I}$.

${ }^{\mathrm{f}}$ Presley et al. (this volume).

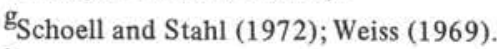

$\mathrm{h}_{\text {Weiss (1969). }}$

${ }^{i}$ Kaplan et al. (1969) for Core 84K.

${ }^{\mathrm{j}}$ Highly variable; data of Kaplan et al. (1969) also show scatter.

reactions in the sediments may cause shifts in sediment-water reactions involving this phase. Not included in the table are the interstitial values of Hendricks et al. for Discovery Deep. In spite of scatter, these values also tend to reflect compositions in the Discovery Deep waters. A point to be made is that there are few indications of any consistent changes in interstitial constituents with depth. It would rather appear that the sediments are permeated with brine of the composition currently discharging into the rift basins and show little evidence of retaining brine of an earlier, different type. As will be shown later, however, the hot brine basin fluids bear little resemblance to interstitial waters associated with evaporite deposits at Sites 225,227 , and 228 , and one may conclude that they have a different history.

Trace and minor constituents, compiled in Table 12, are subject to much greater analytical and manipulative scatter than the major constituents. Nevertheless, examination of the data by various investigators reveals several consistent patterns and invites the following conclusions.

1) $\mathrm{Fe}$ and $\mathrm{Mn}$ concentrations are in the range $50-80$ ppm for both the Atlantis II Deep brines and sediment interstitial waters and have remained so over a period of 7 years. $\mathrm{Fe}$, but not $\mathrm{Mn}$, is depleted in the waters of the Discovery Deep, presumably due to oxidation and precipitation phenomena. To a lesser degree it is also depleted in interstitial waters.

2) $\mathrm{Br}$ and $\mathrm{B}$ are only moderately enriched in the hot brines with respect to Red Sea bottom water and interstitial waters of the metalliferous sediments (less than a factor of 2 ), which implies a sharp depletion with respect to $\mathrm{C} 1$ or total dissolved salts. $\mathrm{F}$ is almost totally depleted in the Atlantis II Deep brines; this has been used by Craig (1969) to show that there has been little contribution by Red Sea bottom water to the hot brine composition.

3) $\mathrm{Sr}$ is enriched five-fold in both hot brines and interstitial waters over Red Sea bottom waters, but this represents a depletion with respect to $\mathrm{Cl}$ or $\mathrm{Na}$. On the other hand, $\mathrm{Li}$, forming few difficult soluble components, maintains concentrations on the order of $5 \mathrm{ppm}$ in both hot brines and interstitial waters; this represents a modest enrichment for $\mathrm{Li} / \mathrm{Cl}$ with respect to normal seawater $(3 \mathrm{X}$ $10^{-5}$ vs. $1 \times 10^{5}$ ).

4) $\mathrm{Zn}, \mathrm{Pb}$, and $\mathrm{Cu}$ show very substantial enrichments with respect to normal or Red Sea bottom waters of approximately 5, 0.5 and $0.3 \mathrm{ppm}$, respectively. Excluding the stored-core samplings of Brooks et al. (1969) (their very high $\mathrm{Zn}$ and $\mathrm{Cl}$ values are possibly artifacts of storage and reaction with galvanized iron box core tubes), these values are not far from means of the interstitial waters, even 
TABLE 12

Minor and Trace Constituents in Fluid Phases of Red Sea Sediment-Hot Brine Systems

\begin{tabular}{|c|c|c|c|c|c|c|}
\hline Element & $\begin{array}{c}\text { Red Sea } \\
\text { Bottom Water }\end{array}$ & $\begin{array}{l}\text { Atlantis } \\
\text { II Deep }\end{array}$ & $\begin{array}{l}\text { Discovery } \\
\text { Deep }\end{array}$ & $\begin{array}{l}\text { Interstitial Water } \\
\text { Atlantis II Deep }\end{array}$ & $\begin{array}{l}\text { Interstitial Water } \\
\text { Discovery Deep }\end{array}$ & $\begin{array}{c}\text { Interstitial Water } \\
\text { Atlantis II }\end{array}$ \\
\hline $\mathrm{Al}$ & - & - & - & $1.7-5.8^{a}$ & $1.7-6.7^{a}$ & - \\
\hline As & - & $<0.1^{b}$ & $<0.1^{b}$ & - & $<0.1^{1}$ & - \\
\hline $\mathrm{Ag}$ & - & - & - & $0.008-0.07$ & $0.03-0.04$ & - \\
\hline B & 5.3 & $10^{\mathrm{c}}$ & $7.5^{4}$ & $7.5-10^{\mathrm{a}}$ & $7.5-13^{a}$ & $8-10^{d}$ \\
\hline $\mathrm{Ba}$ & - & $0.9^{\mathrm{c}}$ & ${ }^{\prime}<0.3^{\mathrm{c}}$ & - & - & $1.0^{\mathrm{d}}$ \\
\hline $\mathrm{Br}$ & 76 & $128^{\mathrm{e}}$ & $119-123 \mathrm{e}$ & $108-142^{a}$ & $92-125^{a}$ & $98^{\mathrm{f}}$ \\
\hline $\mathrm{Cd}$ & - & - & $0.000-0.005 \mathrm{~g}$ & $0.5-1.7 \mathrm{~g}$ & $0.5-0.7 \mathrm{~g}$ & $0.20^{f}$ \\
\hline \multirow[t]{2}{*}{$\mathrm{Co}$} & - & $0.16^{\mathrm{e}}$ & $0.13^{\mathrm{e}}$ & & & \\
\hline & & $<0.001-0.017 \mathrm{~g}$ & $0.001 \mathrm{~g}$ & $0.75-2.9^{a}$ & $1.2-2.2^{\mathrm{a}}$ & - \\
\hline \multirow[t]{2}{*}{$\mathrm{Cu}$} & - & $0.26^{\mathrm{e}}$ & $0.075^{\mathrm{e}}$ & $0.3-4.7 \mathrm{~g}$ & $0.3-0.6 \mathrm{~g}$ & - \\
\hline & & $0.03-0.52 \mathrm{~g}$ & $\begin{array}{c}0.06-0.34 \mathrm{~g} \\
0.014 \mathrm{~h}\end{array}$ & $0.25-1.4^{a}$ & $0.17-0.58^{a}$ & 0.45 \\
\hline $\mathrm{F}$ & 1.6 & $\begin{array}{c}<0.02^{\mathrm{h}} \\
81^{\mathrm{e}}\end{array}$ & $\begin{array}{l}0.051^{\mathrm{e}} \\
0.27^{\mathrm{e}}\end{array}$ & - & - & - \\
\hline $\mathrm{Fe}$ & - & $\begin{array}{c}83-100 \mathrm{~g} \\
82^{\mathrm{i}}\end{array}$ & $0.05-0.15 \mathrm{~g}$ & $16-115^{a}$ & $4.5-29 \mathrm{a}$ & $52^{f}$ \\
\hline I & - & - & $0.03^{h}$ & - & - & - \\
\hline $\mathrm{Li}$ & 0.21 & $4.1-4.7 \mathrm{~g}$ & $\begin{array}{c}4.0-4.1 \mathrm{~g} \\
0.26^{\mathrm{h}}\end{array}$ & $46.6-6.7 \mathrm{~g}$ & $4.6-5.9 \mathrm{~g}$ & $4-7 \mathrm{~d}$ \\
\hline $\mathrm{Mn}$ & - & $\begin{array}{c}82^{\mathrm{e}} \\
83-100 \mathrm{~g}\end{array}$ & $\begin{array}{c}54.6^{\mathrm{e}} \\
56-66 \mathrm{~g}\end{array}$ & $\begin{array}{l}54-89 \mathrm{~g} \\
59-88^{a}\end{array}$ & $\begin{array}{l}25-59 g \\
15-68 \mathrm{a}\end{array}$ & $\begin{array}{l}3.15 \\
70^{f}\end{array}$ \\
\hline Mo & 0.01 & - & - & $0.03-0.3 \mathrm{a}$ & $-(0.3)^{\mathrm{a}}$ & - \\
\hline $\mathrm{NH}_{3}-\mathrm{N}$ & - & - & - & - & - & $<0.55$ \\
\hline $\mathrm{NO}_{2}-\mathrm{N}$ & $<0.001^{c}$ & $(0.001)^{c}$ & $(0.001)^{\mathrm{c}}$ & - & - & - \\
\hline $\mathrm{NO}_{3}-\mathrm{N}$ & $0.11^{\mathrm{c}}$ & $(0.011)^{\mathrm{c}}$ & $(<0.001)^{\mathrm{c}}$ & - & - & - \\
\hline \multirow[t]{2}{*}{$\mathrm{Ni}$} & - & - & $\begin{array}{l}0.002 \mathrm{~g} \\
0.34 \mathrm{~h}\end{array}$ & $\begin{array}{l}0.5-0.8^{\mathrm{a}} \\
2.3-3.5^{\mathrm{e}}\end{array}$ & $\begin{array}{c}0.6-0.75^{\mathrm{a}} \\
2.4-2.9 \mathrm{~g}\end{array}$ & $2.2^{\mathrm{f}}$ \\
\hline & & $0.3-0.52 \mathrm{~g}$ & & & & \\
\hline \multirow[t]{2}{*}{$\mathrm{Pb}$} & - & $0.62^{1}$ & $0.17^{1}$ & $0.25-0.83^{a}$ & $0.4-0.75 \mathrm{a}$ & \\
\hline & & $0.5 \mathrm{j}$ & $0.08-0.21 \mathrm{~g}$ & $3.0-4.2 \mathrm{~g}$ & $3.0-3.9 \mathrm{~g}$ & - \\
\hline $\mathrm{PO}_{4}-\mathrm{P}$ & $0.02^{\mathrm{c}}$ & $(0.02)^{\mathrm{c}}$ & $<0.01^{\mathrm{c}}$ & $2-13 a$ & $<1-10^{\mathrm{a}}$ & - \\
\hline $\mathrm{Se}$ & - & $0.15^{b}$ & $<0.05^{b}$ & - & $<0.05$ & - \\
\hline $\mathrm{SiO}_{4}-\mathrm{Si}$ & $0.34 \mathrm{c}$ & $(12.3)^{\mathrm{c}}$ & $(15.7)^{\mathrm{c}}$ & 4-9a & $3-5 a$ & - \\
\hline \multirow[t]{2}{*}{$\mathrm{Sr}$} & 9.2 & $48^{\mathrm{e}}$ & $46^{\mathrm{e}}$ & $43-58^{a}$ & $53-83 a$ & \\
\hline & & $45^{\mathrm{i}}$ & $44 \mathrm{i}$ & $55-72 \mathrm{~g}$ & $58-72 \mathrm{~g}$ & $45^{\mathrm{d}}$ \\
\hline $\mathrm{U}$ & 3.3 & $0.48 \mathrm{k}$ & - & - & - & - \\
\hline \multirow[t]{2}{*}{$\mathrm{Zn}$} & - & $5.4 \mathrm{e}$ & $0.77^{\mathrm{e}}$ & $1-13^{a}$ & $1-13 a$ & $15^{f}$ \\
\hline & & $4.6-10 \mathrm{~g}$ & $0.8-2.8 \mathrm{~g}$ & $5-400 \mathrm{~g}$ & $1-168 \mathrm{~g}$ & \\
\hline
\end{tabular}

Note: All values in ppm.

${ }^{a}$ Hendricks et al. (1969) (chiefly chemical data cited).

b Kaplan et al. (1969).

${ }^{c}$ Miller et al. (1966).

${ }^{\mathrm{d}}$ Manheim et al. (this volume).

${ }^{\mathrm{e}}$ Brewer and Spencer (1969).

${ }^{\mathrm{f}}$ Presley et al. (this volume.)

$\mathrm{g}_{\text {Brooks et al. (1969). }}$

$\mathrm{h}_{\text {Brewer et al. (1966) }}$

${ }^{\mathrm{i}}$ Faure and Jones (1969).

j Delevaux et al. (1967).

$\mathrm{k}_{\mathrm{Ku}}$ (1969).

though the latter show a great deal of scatter. There is a sharp depletion in the heavy metals on moving from the Atlantis II to Discovery deep waters, probably owing to coprecipitation of the metals with iron.

Selective precipitation of the brine metals is clearly responsible for the formation of the heavy metal deposits in the Atlantis II Deep. Miller et al. (1966) and Craig (1969) stressed that the metal concentrations in the brines are probably not unusual for sedimentary brines associated with evaporite deposits and require no input of volcanic emanations or other unusual sources. On the other hand, the lead isotope data appear to require some mantle or volcanic associations for the brine and sediment lead (Delevaux and Doe, this volume, and references cited). A number of the constraints on the system have been discussed in great detail by Craig (1969), but in the writer's opinion no subsequent evidence has been uncovered that clarifies the uncertainty regarding possible metal source. 
Interstitial Waters from Non-Hot Brine Sites and Their Significance

As has been shown by Manheim et al. (this volume), Sites 225, 227, and 228 reveal marked interstitial increases in chlorinity and total salt content with depth, reaching near-saturation $(\mathrm{NaCl})$ values in the late Miocene evaporite strata (Figure 5). The 16 percent increase in interstitial chlorinity at Site 229 is much more gradual than at the preceding sites, but in view of the extraordinarily rapid accretion rate of the sediments, is believed to signify probable presence of evaporites at depth at this site as well. Likewise, a single sample from Site 230 already showed such strong enrichment in chlorinity above that of bottom water $\left(33.0\right.$ versus $22.4 \mathrm{Cl}^{\circ} \%$ ) at a depth of a few meters, that halite deposits could not have been far below. Thus, it appears that salt deposits and associated saturated brines are omnipresent in the southern half of the Red Sea.

Though the "non-hot brine deep" brines resemble the hot brines in total salt content, their ionic composition is markedly different as may be seen in Table 13 . Here, the sodium chloride component corresponding to total sodium in the brines is subtracted from the values and the molar proportions of the remaining major components is listed. It is significant that each site has its own chemical "signature."

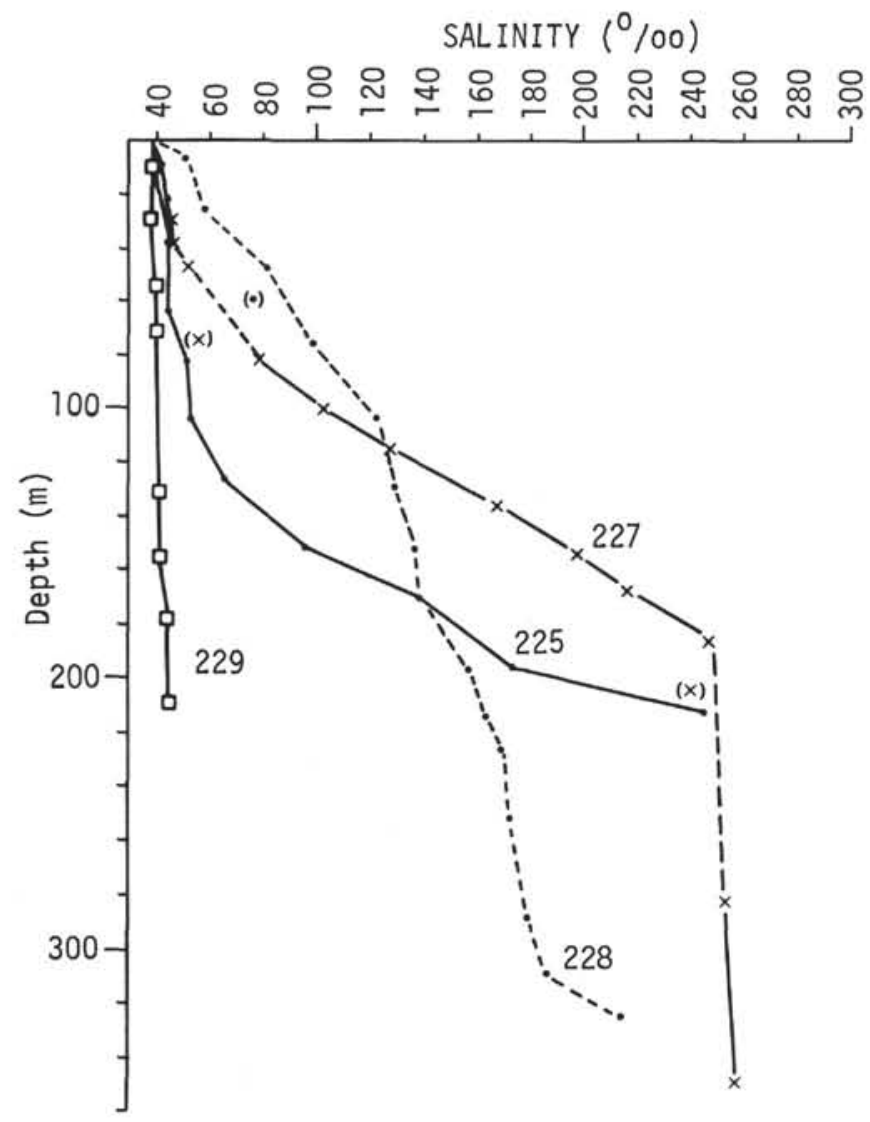

Figure 5. Distribution of interstitial salinity (total dissolved salt) with depth in Sites 225, 227, 228, and 229 (Red Sea).
Below continuous halite beds, we can anticipate little communication between the fluids and those above, unless faulting or fracturing rupture the salt structure sufficiently to create breaches in it. Thus, the fluids are representative of interstitial waters either buried with the evaporites or emplaced before final consolidation and sealing of the sediments. At the upper margin of the evaporites, leaching and diffusion away of solubles create solution breccias and other disconformities, while allowing soluble constituents to permeate overlying strata. Some constituents, such as $\mathrm{K}$ and $\mathrm{Mg}$, are clearly removed from solution by reaction with overlying rocks, whereas nonreactive species such as interstitial $\mathrm{Cl}$ more accurately reflect the salt migration progress (Manheim et al., this volume). The fact that dolomites within or just above the evaporites are more stoichiometrically perfect than Ca-rich protodolomites higher in the section may reflect the greater exposure to $\mathrm{Mg}$-rich interstitial solutions at the evaporite juncture.

Though trace metal (Table 14) analyses are not available from the most concentrated interstitial brines, they already exhibit significant enrichments in $\mathrm{Cu}$ and $\mathrm{Zn}$ at intermediate salt concentrations.

Isotopic measurements on the interstitial waters are particularly significant because they offer the potential of tracing the source and history of the waters, in a way unrelated to the salt concentrations they may have acquired

TABLE 13

Mole Percent of Components in Non- $\mathrm{NaCl}$ Residue of Atlantis II Hot Brine Salts and Interstitial Waters of Sites 225, 226, and 227

\begin{tabular}{l|c|rrrr}
\hline & \multirow{2}{*}{$\begin{array}{c}\text { "Hot Brine" } \\
\text { Atlantis II Deepa }\end{array}$} & \multicolumn{4}{|c}{ Interstitial Waters b } \\
\cline { 3 - 6 } & Site 226 & Site 225 & Site 227 & Seawater \\
\hline $\mathrm{Mg}$ & 5.1 & 4.6 & 22.2 & 26.1 & 31 \\
$\mathrm{Ca}$ & 20.6 & 23.9 & 4.2 & 6.4 & 6 \\
$\mathrm{~K}$ & 7.7 & 8.4 & 9.5 & 0.9 & 6 \\
$\mathrm{Cl}$ & 59.9 & 61.8 & 51.8 & 65.2 & 40 \\
$\mathrm{SO}_{4}$ & 1.4 & 1.2 & 12.2 & 0.5 & 17 \\
\hline
\end{tabular}

aFrom Brewer and Spencer, 1969.

bFrom Manheim et al,, this volume.

TABLE 14

Selected Minor Constituents in Interstitial Waters from Presley et al. (this volume)

\begin{tabular}{c|c|rrrrrr}
\hline & & \multicolumn{7}{|c}{$\mathrm{ppm}$} \\
\cline { 3 - 8 } Depth (m) & Sample & $\mathrm{Fe}$ & $\mathrm{Mn}$ & $\mathrm{Cu}$ & $\mathrm{Zn}$ & $\mathrm{Cd}$ & $\mathrm{Ni}$ \\
\hline \multirow{2}{*}{214} & $225-28-1$ & 2.6 & 0.8 & 0.5 & 4.6 & 0.20 & 5.0 \\
166 & $228-21-2$ & 3.0 & 3.1 & 0.4 & 1.6 & 0.07 & 1.0 \\
0.5 & $226-1-1$ & 52.0 & 70.0 & 0.48 & 15.0 & 0.20 & 2.0 \\
\hline
\end{tabular}

atlantis II Deep. 
through leaching of solid evaporites. The deuterium (Friedman and Hardcastle, this volume) and $\mathrm{O}^{18}$ data (Lawrence, this volume) both show indications of decreasing heavy isotope content with depth at Sites 225 , 227, and 228. This behavior does not reflect fresher water environmental stages during post-Miocene time (Fleisher, this volume), judged by the paleontological data. In fact, the change of isotopic ratios to "lighter" values proceeds continuously with increasing interstitial salinity (Figure 6). From this we must conclude that the waters are diffusing upward from a "lighter" isotopic reservoir associated with the evaporitic strata, in the same manner that soluble salts are diffusing upward driven by the concentration gradient. In the former case, however, there cannot be a steady-state system, for there is not unlimited water reservoir, as there is concentrated brine that can be continuously formed by leaching the halite, anhydrite, and other solid evaporite minerals.

Deuterium concentrations (ratios) at Sites 225 and 227 (Figure 6) show very close correspondence to salinities approaching saturation with halite (at the boundary of occurrence of halite in the section). At this point, however, interstitial fluids from Site 227, which penetrated another 166 meters into the evaporites, drop very sharply in $\delta \mathrm{D}$ to reach relatively constant levels of -2 to $-4 \%$ within the evaporite strata. The sharpness of the drop is attributed to the very poor diffusional permeability of the anhydritichalite strata. For all practical purposes diffusive or bulk fluid movements within the evaporitic strata at Site 227 are probably interdicted (see diffusion studies later). Probably, evaporites had not yet been penetrated deep enough to find "original" interstitial brines unaffected by diffusion from above; that is, at a still greater depth "lighter fluids" might have been found.

Figure 7 , plotting $\delta \mathrm{D}$ against $\delta \mathrm{O}^{18}$ shows clearly that the interstitial fluids from Sites 225,227 , and 228 are not part of the Atlantis II Deep hot brine system, as delineated by

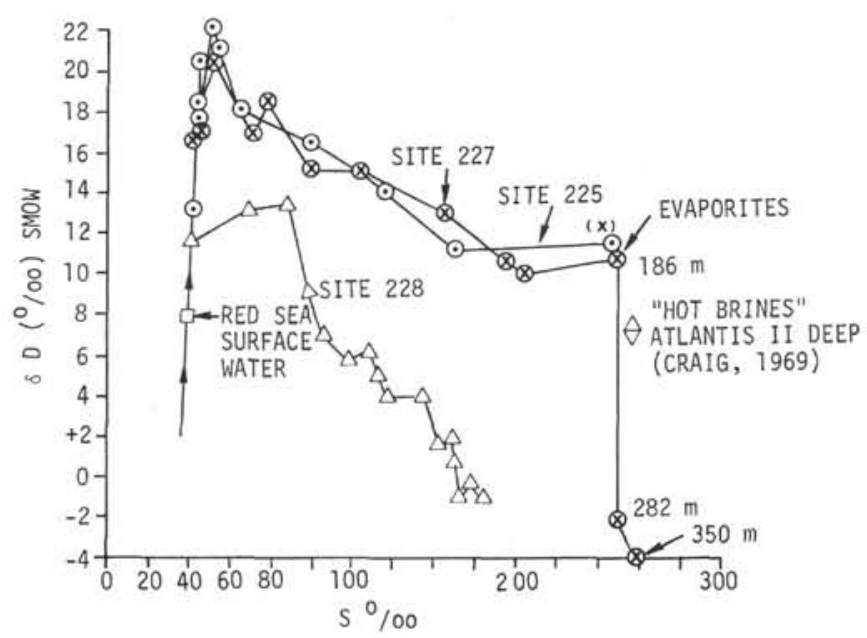

Figure 6. Distribution of interstitial $\delta \mathrm{D} / \mathrm{H}$ (SMOW) with depth, Sites 225, 227, and 228. Arrows refer to salinity- $\delta \mathrm{D} / \mathrm{H}$ relationships applicable to normal Red Sea waters (Craig, 1969).
Craig (1969). Lawrence (this volume) has pointed out that the deeper samples at Site 227 show a highly anomalous behavior, falling to very low $\delta 0^{18}$ values without corresponding depletion of $\delta \mathrm{D}$. Since there is no significant reservoir of $\mathrm{H}$ within the sediments, Lawrence was forced to conclude that the $\delta \mathrm{O}^{18}$ values had been depressed by the addition of low $\delta \mathrm{O}^{18}$ waters from reaction with basalts or other volcanic rocks at depth. Similar decrease of oxygen isotopic ratios with depth has been observed elsewhere (Lawrence, this volume), attributed to diagenetic reaction with silicate rocks. This relationship would seem to render it highly unlikely that long-distance undersea transport of brines could have taken place without changing $\delta \mathrm{D} / \delta \mathrm{O}^{18}$ relationships.

\section{Diffusion and Migration of Ions and Gases}

In order to measure the capacity of the sediments and rocks to permit ionic diffusion through their interconnected pore spaces, special electrical resistivity measurements were undertaken at Sites 225, 227, 228, and 229 (see site reports and Manheim, this volume, Geochemical Methods). Electrical resistivity of pore fluids had been used successfully on Leg 22 for measurement of diffusion properties of unconsolidated sediments, and these properties were regarded as particularly important to the understanding of intrastratal migration of dissolved species in the Red Sea geochemical systems. It has been shown previously that "formation factor" or the ratio of whole rock resistivity to resistivity of the entrapped pore fluids alone is inversely proportional to the diffusion constant for ions and molecules moving within interconnected pore spaces in rocks, provided that clays or other solid particles do not carry an appreciable proportion of the current through the bulk rock. At the same time it has also been long known that formation factor, $(F)$ varies with porosity according to the relationship $F=a / \phi^{n}$ where $a$ is a constant

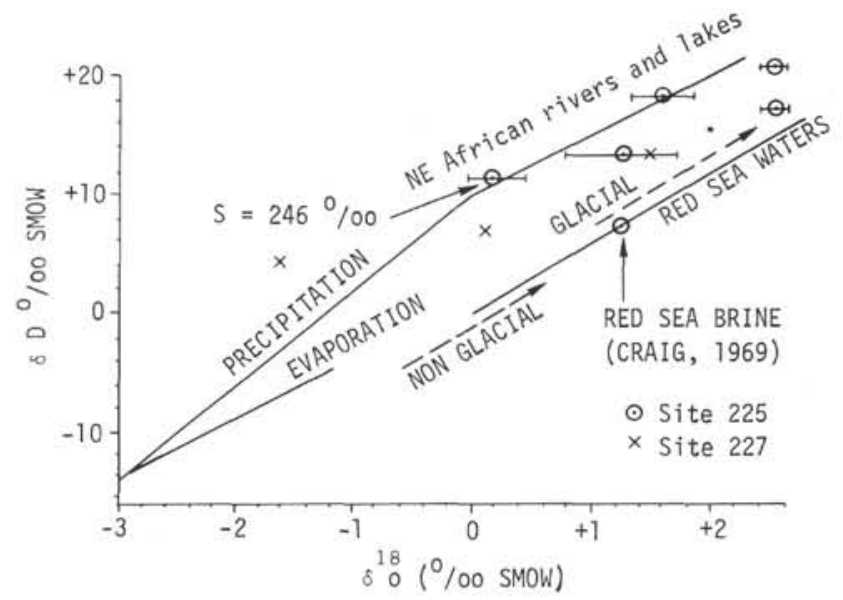

Figure 7. Deuterium-oxygen isotopic diagram for waters of Red Sea region (modified from Craig, 1969) with interstitial water data for Sites 225 and 228 from Friedman (this volume) and Lawrence (this volume). 
close to $1, \phi$ is porosity, and $n$ is a factor depending largely on the cation exchange capacity (clay content) of the rock. The exponent may vary from less than 2 for "clean" particle systems such as sands or limestones to 5 for montmorillonitic clays or shales.

Plots of $F$ against depth and porosity are given for Sites 225, 227, 228, and 229 in Figures 8 through 11. These bear out in a general way the decreasing diffusive permeability of the post-Miocene carbonate-rich sediments with depth. Values of $F$ range from between 2 and 3 in the uppermost sediments to more than 10 at depth. Taken at face value, this means that the uppermost sediments permitted diffusion of the dominant dissolved species (i.e., $\mathrm{NaCl}$ ) at a rate of about $1 / 2$ to $1 / 3$ that in free solution, whereas with depth the rate decreased to less than $1 / 10$. In the cemented palagonites (rocks, which though still having considerable porosity, had become rigidly cemented and ringing hard to the hammer) at Site 229, diffusive permeability fell tc about $1 / 30$ th of free solution values.

The diffusive properties of rocks at Site 229 are interesting because of gas occurrence strong enough to cause abandonment of the site. McIver has pointed out that the gas contents in the canned samples were among the highest found in the DSDP program to date. As much as 16 percent methane (by volume) was found at 61 meters, total values falling off with depth. We should recognize, however, that the total amounts recovered in the cans are probably subject to artifacts in the canning process and certainly do not represent original gas content, because of the opportunity for loss of gas during raising of cores. Moreover, on-deck observation of core recovery showed no significant diminution of total gas content, judged by the excess pressure released when removing the core nose and separation of core sections in their liners while on deck and in storage racks preparatory to core splitting. The hydrocarbon to bitumen ratios of 0.2 to 0.45 (McIver, this volume) suggest that the petroleum-hydrocarbon generation, though not very far along, has begun, even though the probable in situ temperatures have not reached values normally regarded as necessary for these processes.

Gas chromatographic (shipboard) analysis of the exsolved gas showed a continuing increase in the ethane/methane ratio with depth. Although the palagonite layer is demonstrably less permeable to diffusion than overand underlying layers, it equally clearly does not seem to form an absolute barrier to gas permeation (Figure 12). In contrast, $\mathrm{CO}_{2}$ increase with depth is interrupted by the palagonite, probably owing to uptake of $\mathrm{CO}_{2}$ on weathering silicate rocks (glassy tuffs) to form $\mathrm{CaCO}_{3}$. Below the palagonite the $\mathrm{CO}_{2}$ content of the gas again increases irregularly with depth. Regrettably, these data refer only to the gas recovered with the cores, and we have no way of knowing what the total original gas concentrations were, nor whether distortion of the proportions of gases occurred as a result of preferential loss of some of the constituents. Construction of a pressure core barrel to capture sediments under in situ pressures has been authorized by the DSDP and should permit a major breakthrough in knowledge about gas distribution and migration in marine sediments.

As one might expect from their low porosity, rocks within the evaporite sequences showed correspondingly

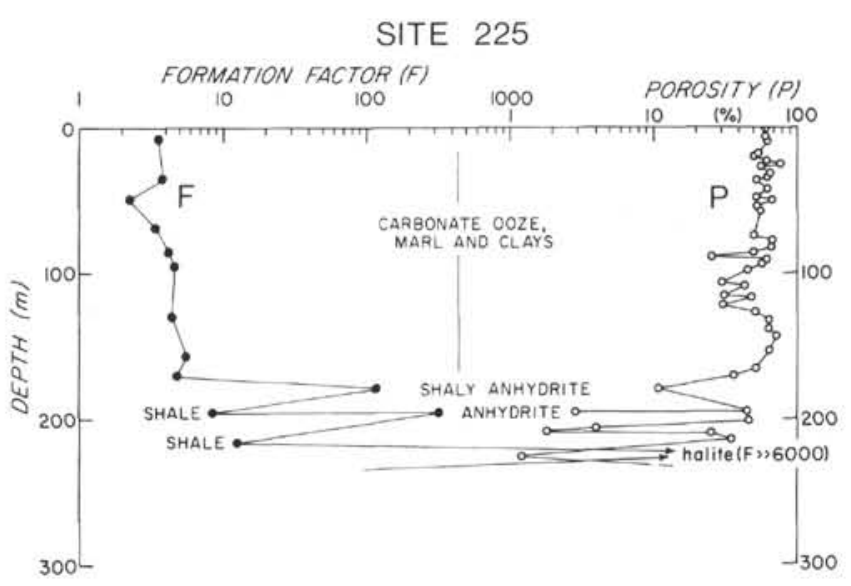

Figure 8. Distribution of formation factor and porosity with depth at Site 225.

SITE 227

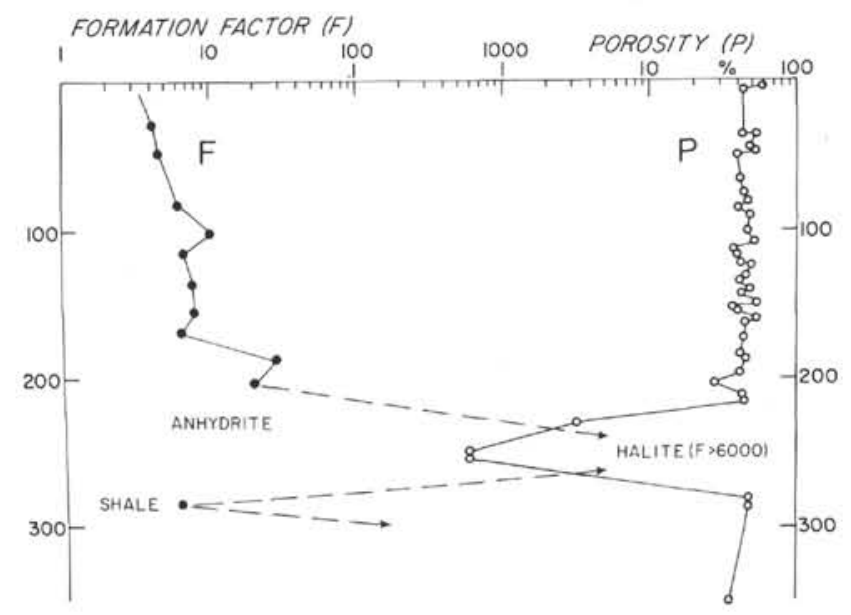

Figure 9. Distribution of formation factor and porosity with depth at Site 227.

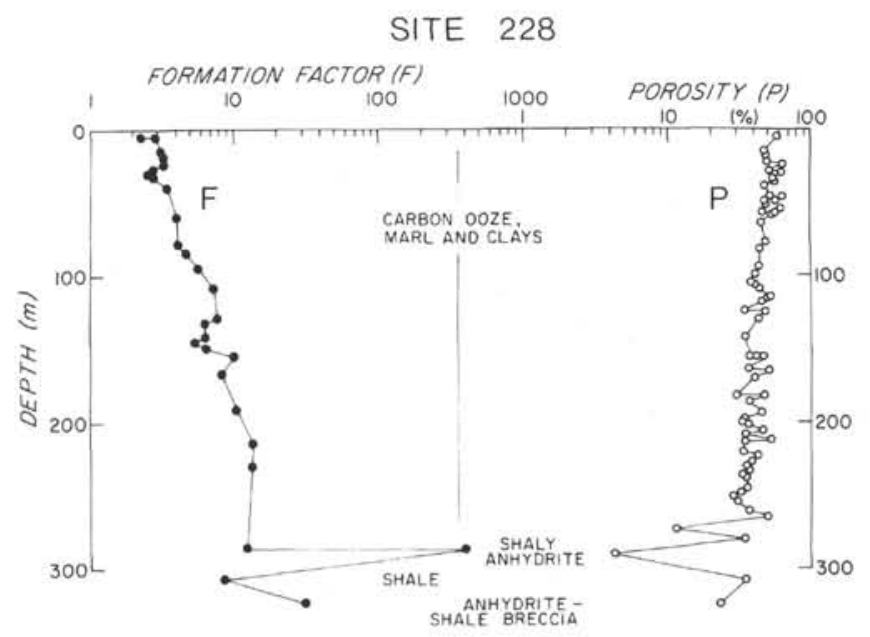

Figure 10. Distribution of formation factor and porosity with depth at Site 228. 
SITE 229,229A

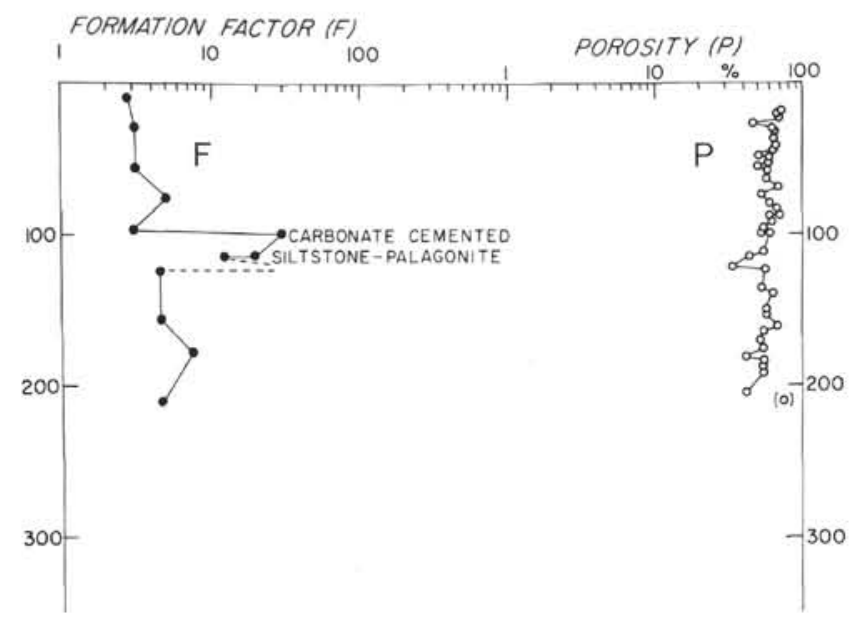

Figure 11. Distribution of formation factor and porosity with depth at Hole 229.

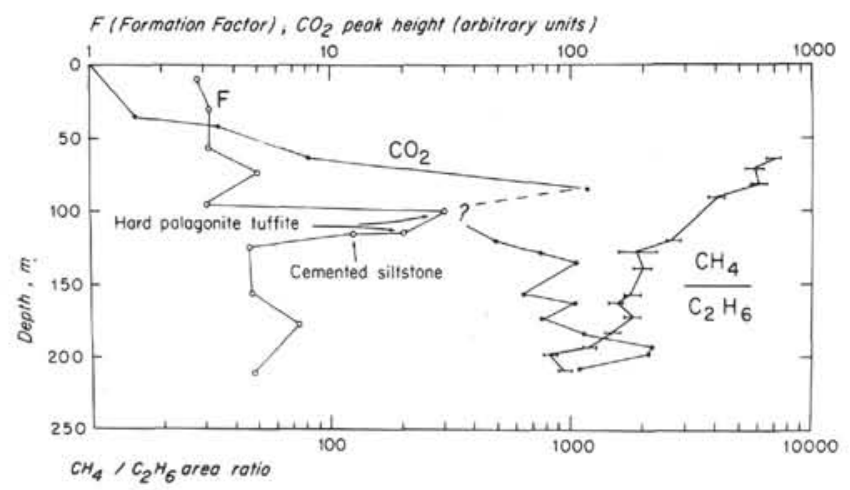

Figure 12. Distribution of formation factor and core gas with depth at Hole $229 \mathrm{~A}$.

high formation factors or low diffusion coefficients calculated from these. Nonanhydritic shales within these strata did not display any significant change in diffusion properties from shales overlying the evaporites. This might be expected in one sense, since these shales are unlikely to lose any further moisture (porosity) by consolidation processes. On the other hand, cementation processes that might have been enhanced in the strong brine zone have not materially changed permeability of the shales. Diffusive permeability within the anhydrites appears to be proportional to their content of clay minerals. It ranges from somewhat less than 100 to several hundred times less than free in solution. On the other hand, halite specimens tested were off scale on our resistivity meter, corresponding to $F$ values greater than 6000 . This corresponds to literature data showing that halites are among the most impermeable rocks known, exceeding granites and crystalline basalts in this respect.

The above discussion has been restricted to the properties of the rocks as measured onboard ship. We must recognize that the increase in temperature with depth in the hole will increase the diffusion constants by factors of up to two or more depending on the temperature reached. To a less predictable degree, the release of pressure on the cores will also change the resistive properties.
Assuming a steady-state salt diffusion profile has been attained by the evaporitic sites (Figure 5) and utilizing the formation factor data to get limits on diffusion coefficients, we may calculate rough limits on the volume of dissolved salts removed from the evaporite layers by leaching and upward diffusion. At Site 225, for example, we take a gradient from 180 meters to 210 meters as $100 \mathrm{~g} / \mathrm{kg}$ total salt $/ 30$ meters or about $4 \times 10^{-5} \mathrm{~g} / \mathrm{cm}^{3}$ per $\mathrm{cm}$ of depth. Formation factors at a presumed temperature of about $50^{\circ} \mathrm{C}$ are about 5 and 120 for shale and anhydrite, respectively. Then, given $\mathrm{NaCl}$ diffusion coefficient of about $2 \times 10^{-5} \mathrm{~cm}^{2} / \mathrm{sec}$ for free solution, the appropriate diffusion coefficients are $4 \times 10^{-6}$ and $1.7 \times 10^{-7} \mathrm{~cm}^{2} / \mathrm{sec}$ for shale and anhydrite, respectively. Then, $J=-k d c / d x$, where $J$ is the flux of salt in $\mathrm{g} / \mathrm{sec}$ across a $1-\mathrm{cm}^{2}$ area, $k$ is the diffusion coefficient for $\mathrm{NaCl}$, and $d c / d x$ is the concentration gradient with depth. The fluxes are $4 \times 10^{-4}$ and $1.7 \times 10^{-5} \mathrm{~g} / \mathrm{yr}$ for shale and anhydrite, respectively. This means that at the present time from 0.1 to 1.8 meters of rock salt are leached away from the evaporite boundary per million years at Site 225 . These magnitudes are perhaps large enough to give rise to some of the crinkly bedded anhydrites with thin shale interbeds in the uppermost part of the evaporite sequences; that is, some of the anhydrite beds are lag remnants of anhydrite dispersed in larger amounts of halite. The total amount of interstitial salt in a $1-\mathrm{cm}^{2}$ column above a depth of 180 meters at Site 225 is approximately $540 \mathrm{~g}$. At the fluxes calculated above, it would require about 1 million years to replace all the interstitial salt in the column for shales at the 180-210 meter zone, whereas it would require 31 million years to do so if anhydrites characterized this boundary. If the latter were so, it would mean that the assumption of steady state is not correct; that is, that the amount of interstitial salt in the column is still increasing. In actual fact, the strata between 180 and 210 meters are intermixed anhydrites and shales, and the shape of the interstitial salt gradient does suggest that steady state (closer approach to a straight-line gradient, somewhat steeper with depth) has not been attained. A more straight-line (steady-state-like) gradient is evident for Sites 227 and 228 (Figure 5).

\section{ORIGIN OF THE EVAPORITES}

Overwhelming evidence points to a shallow-water evaporite pan origin of the evaporites penetrated at the Leg 23B sites.

1) Both petrographic evidence and high $\mathrm{Sr} / \mathrm{Ca}$ values (Stoffers and Kühn, this volume) indicate that much of the anhydrite is primary. Stability considerations for gypsumanhydrite indicate that the anhydrite must have been deposited in very warm conditions such as those commonly found in shallow evaporating pans.

2) The bromine indicator of evaporite environment (Kühn, 1953) yields water depths of a few meters depth (Stoffers and Kühn, this volume).

3) Nodules and oncolites in the anhydritic layers resemble remnants of stromatolitic deposits typical of a shallow-water brine (Stoffers and Kühn, this volume).

4) The chemical nature of the evaporites, and the interstitial waters associated with them, shows great variation from site to site. This is typical for sabkha-like 
deposits. Moreover, late-stage evaporites or their leachates are present (chlorides of the tachyhydrite-bischofite series). These deposits cannot readily be preserved under deep-water conditions (Braitsch, 1971).

5) Hydrogen and oxygen isotopic ratios of the interstitial waters, especially those trapped below substantial halite beds, and hence protected from mixing with overlying waters, show strong indications of meteoric water influence. This influence also extends to carbon and oxygen isotopes in carbonate phases that have equilibrated or partially equilibrated in brines within or near the evaporitic strata. A deep-water evaporite basin the size of the Red Sea would necessarily contain strongly evaporated (seawater) brines having correspondingly heavier, not lighter, isotopic contents.

Stoffers and Kühn (this volume) have suggested that only the last evaporites deposited in the Red Sea basin may have been shallow water in origin. Earlier evaporites in the very thick series already known from drill holes are postulated by the above authors to have been laid down in a deep basin such as was proposed by Schmalz (1969). This concept agrees with the views of Hassan and El-Dashlouty (1970), who attributed a deep origin to evaporites in the Gulf of Suez by virture of their concentric distribution, with late-stage evaporites in the center. Their dominant evaporite basin occurs in lower-middle Miocene(?) and is open ended to the Red Sea proper. However, the evaporites extend into Aquitanian (basal Miocene and possibly Oligocene). Total evaporitic thickness aggregates more than 3600 meters.

The deep-water concept conflicts with that of Ross and Schlee (in press) who envisage doming of the Red Sea area in Paleogene time, as evidenced by widespread absence of Oligocene and early Miocene strata in the deeper drill holes. Since the rock salt-evaporite series was preceded by a normal marine Middle Miocene phase, indicated by the planktonic fauna of the Upper Globigerina group (Ahmed, 1972, and references cited), one would presume that a deep basin should have also allowed more complete and thicker early and early-middle Miocene sequences. Moreover, thin salt, anhydrite, and gypsum found in boreholes on land in Ethiopia extend continuously to thicker evaporites in the Red Sea (Pratsch, 1973, oral communication). This suggests that the environments of deposition both in the Red Sea and in present shore areas at the time of evaporite formation were similar, probably closer to the sagging shallow-water model of Ross and Schlee (in press).

One independent possibility for determination of the depth of water for earlier evaporites in the Red Sea sequence is the vesicle-size technique as elaborated by Moore (1965) and Jones (1969) for submarine basalts. Through the courtesy of J. C. Pratsch and C. Burk (Mobil Oil Co., Princeton, N. J.) thin-sections of basic igneous rocks from Mobil/Exxon's Red Sea B-1 well, in the Ethiopian sector of the Red Sea (see figure in Ross and Schlee, in press), were received and examined by $G$. Thompson (Woods Hole Oceanographic Institution). These rocks consist of submarine, chloritized basalts having unusually large quantities of coarse-grained pyroxenes, partly altered to secondary calcite, chlorite, and zeolites. The basalts underlies the evaporites at depths of about 2100 to 2800 meters and contain vesicles. The interpretation of depths from such vesicles is complicated, however, by observations of Aumento (1971) who found that vesicles were not only found in shallow igneous rocks on the Mid-Atlantic ridge, but also in deep water zones, evidently through the agency of excess volatiles. Thus, until these relationships are clarified, basalts cannot be used as a definitive indication of water depth of extrusion.

In conclusion, the writer regards the origin of deposition of the sequence of evaporites in the Red Sea unsettled on present evidence. No doubt a careful examination of evaporitic rocks at depth from more centrally located drill holes, bearing in mind the lines of exploration outlined earlier, would clear up this question, and there may be structural or other lines of argument, not currently known to the writer, that might help decide the matter.

\section{ORIGIN OF THE HOT METALLIFEROUS BRINES}

This treatment will not recapitulate extensive previous discussions of the controversial question (e.g., Craig, 1969) but will add the new information and constraints gained in the course of the Red Sea drillings to provide a brief synthesis of the genesis of the hot brines. Major facts and conclusions that bear on the genesis follow:

1) As summarized by Craig (1969), the hot brines' water has a hydrogen and oxygen isotopic composition that falls in the range of normal Red Sea waters. The volume and heat of discharging brines in the central Red Sea area, as well as their consistent composition over a period of years, indicate that they are issuing from permeable reservoirs of considerable extent.

2) Strongly saline interstitial waters associated with evaporites at Sites 225, 227, and 228 have chemical and isotopic composition very different from those of the hot brines. The evaporite-associated waters show evidence of contributions of light "meteoric" waters to the fluids trapped with the evaporites. Moreover, the very poor permeability of the rocks in the late Miocene evaporitic sequence precludes discharge of even minor amounts of brines from them, if similar lithologies characterize the evaporitic zones consistently. "Cold" brine deeps such as those reported by the Valdivia expeditions (Bäcker and Schoell, 1972) may owe enhanced salt concentrations to leaching of salt from outcropping salt formations in local basinal traps, or diffusion from salt beds at shallow depths below the sea floor.

3) During R/V Chain Cruise 100 to the Red Sea in the Spring of 1971 , piston cores on the flanks of the hot brine deep, 300 meters above the present brine zone, yielded metal-rich layers (up to $2 \% \mathrm{Cu}$ ) at about 8 meters below the sediment surface (Manheim, in press). Stratigraphic evidence suggested an age of 100,000 years or more. These data imply existence of brine discharge well before emplacement of the known metalliferous deposits, which began about 13,000 years ago (Hackett and Bischoff, 1973), though perhaps at different discharge points and/or in lower volumes than during the latest period.

4) Whereas the concept by Craig (1969) that the hot brines formed from normal Red Sea water seems well documented, his extraordinary long-distance plumbing, or subterranean transport of brines from the southern end of the Red Sea, up to $900 \mathrm{~km}$ to the hot brine deeps is not. 
His placing of a presumed "source" at this point depends on the coincidence of isotopic measurements of present-day waters here with similar values of $\delta \mathrm{D} / \delta \mathrm{O}^{18}$ in the hot brines. A subsidiary argument based on $\mathrm{Ar}$ and $\mathrm{N}$ in the brines is subject to a number of assumptions and is not entirely clear. The present isotopic studies on interstitial brines at Sites 225,227 , and 228 , show that one should expect influence on interstitial isotopic ratios by diagenetic reactions between fluids and host rocks, including both carbonates and silicates. The long-distance plumbing concept postulates virtually complete lack of reactivity of the brines and must be rejected as unrealistic (Baturin et al., 1969). Moreover, there is no indication of how normal Red Sea water could penetrate subsurface formations in the southern end of the Red Sea against density gradients (i.e., increasingly saline fluids at depth, as has been demonstrated in this study). No hydrodynamic mechanism has been adduced which would permit such a flow direction, even if the unprecedented rapidity of fluid movement over the great distance were allowed. Another difficulty in Craig's ingenious but improbable plumbing system is that his geographic relationships linking salinity and isotopic data apply only at present, whereas the waters now discharging into the rift deeps must have entered the system at a minimum, many thousands of years ago. At the earlier date an identical hydrochemical pattern for the Red Sea would have been highly unlikely, particularly in the light of paleoenvironmental evidence (Deuser and Degens, 1969; Milliman et al., 1969).

5) Origin of the hot brines and metalliferous sediments must take into account the origin of the leads. Evidently, some contact between the brines and mantle-associated rocks is needed to provide the lead isotopic signature (Delevaux and Doe, this volume). Basalts recovered in the Leg 23 operations showed little significant evidence of chemical leaching (Coleman, this volume). However, water-laid volcanic tuffs are known from drill holes through the Miocene evaporite sequence (Pratsch, 1973, oral communication) and could provide metals within sedimentary horizons.

The writer favors the hypothesis that the brines are discharging from ruptured subevaporite clastic or permeable carbonate aquifers, possibly corresponding in stratigraphic position to the Globigerina group of middle Miocene age, Overlying evaporites of late Miocene age formed the necessary hydrodynamic seal (aquiclude). The connate waters of these strata (Neumann and Chave, 1965) were marine waters of relatively normal Red Sea salinity originally, but in time became very salty through leaching of soluble evaporitic minerals and ionic diffusion from overlying (later-deposited) evaporitic rocks. The strata are presumably in hydrodynamic continuity from the shallow shelf area of the Red Sea to the deep central rift zone. Thus, when the evaporite layers were breached by the central Red Sea rifts, a powerful hydrodynamic gradient was mobilized and enabled discharge of the heavier brines into the bottom of the deeps. Figure 13 illustrates this in schematic fashion for a section from the Saudi Arabian shelf near Jiddah to the Atlantis II Deep.

The contrast in brine density between the Atlantis II and Discovery deeps brines and normal Red Sea water is about
0.10 Sp.G. units. The actual configuration of pre-evaporite (less likely, in traevaporite) aquifers is not known, but for the purpose of illustration, an extension of the heavy-brine-containing aquifer 500 meters above the discharge point (but below the evaporitic cover strata) would correspond to a normal artesian head of 50 meters (i.e., elevation of aquifer recharge point 50 meters above sea level). Such a head would be more than adequate to maintain powerful artesian flow, including erosion of submarine strata by sapping. Actual heads might be still greater, for elevation differences might be as large as 2000 meters.

A noteworthy fact about the known hot brine deeps is that they are located at a minimum distance between rift zone and both shores for the southern half of the Red Sea; that is, the hydraulic gradient for subevaporite aquifers is a maximum here. No supraevaporite, subsurface flow is
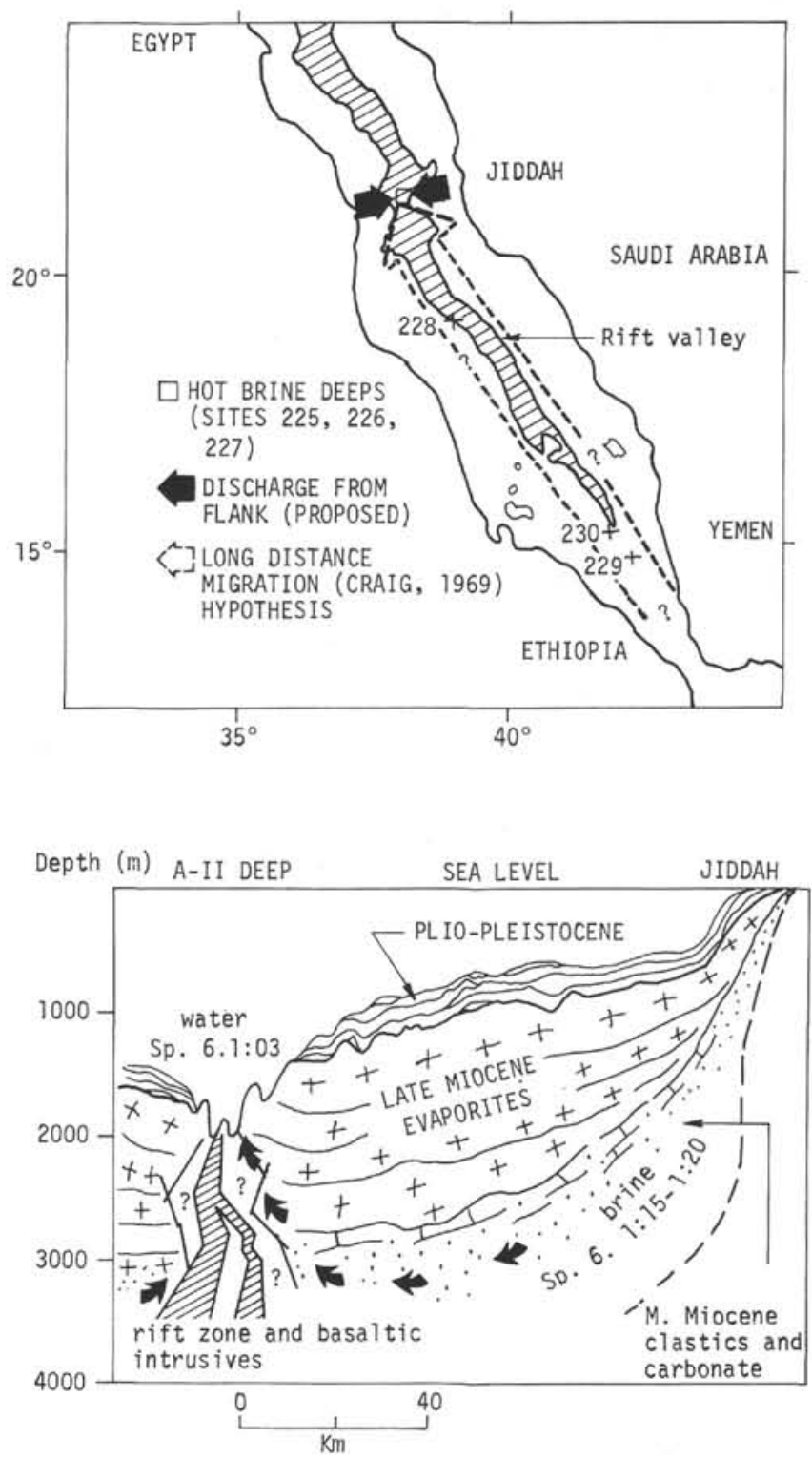

Figure 13. Schematic diagram showing proposed brine discharge path from flanks of Red Sea to Atlantis II Deep. Crosses with numbers refer to drill sites. 
regarded as likely, because sealing beds adequate to confine fluid flow and maintain a hydraulic head are absent. Here again, the factors favoring a flank source of discharging brines make it easy to explain isolated discharge points in central positions in the Red Sea. In a long-distance travel from the southern terminus of the Red Sea, one must ask the question of how a pressure gradient greater than the flanking system could be developed, considering the "frictional" losses with distance, and why hot brines are not found in intervening parts of the central rift system. Careful study of this area by the Valdivia expedition has located only several "cold" brine deeps (e.g., Sudan, Suakin deeps) that show no evidence of forcible discharge of deep (and hot) brines (Bäcker and Schoell, 1972).

As mentioned earlier, the "normal" character of entrapped seawater in the presumed aquifer strata would account for its isotopic character, somewhat modified by exchange with evaporites. $\mathrm{Mg}$ would be reduced to low levels by reaction with carbonates to form dolomite, and soluble $\mathrm{Ca}$, whereas the sulfate content would be controlled by equilibrium with solid anhydrite. Minor and trace constituents in the brine would be leached from the sediments and possibly from pyroclastics by the high ionic strength brines. Temperatures can easily be accounted for by normal thermal gradients. For example, if we assume the discharging brines originally resided at a depth of 2000 meters below the sediment surface, a gradient of only $4^{\circ} \mathrm{C} /$ meters (low for Red Sea conditions) would yield an in situ temperature of $103^{\circ} \mathrm{C}$, assuming surface sediment temperature of $23^{\circ} \mathrm{C}$. We may presume some cooling took place during transit from original positions to the discharge point; on the other hand, heat could also have been contributed by newly emplaced basalts, but would not necessarily be required.

During past evaporative epochs associated with eustatic falls in world sea levels, the relative effect of hydraulic heads would probably be increased, since there is evidence that although sea levels were probably lowered and salinities increased, the latter remained far from concentrations needed to precipitate gypsum (Manheim et al., this volume). Were a hydraulic level above sea level present at the upper end of the continuous aquifer system beneath (possibly also between) the poorly permeable evaporitic covering strata, hydraulic heads would be greatly enhanced, perhaps even doubled. One might suggest that past "hot brine" discharge episodes were triggered during such regressions of sea level and should thus correlate with the lithified zones discussed by Milliman et al. (1969). If this picture is correct, we may be on a declining end of a discharge cycle, even though short-term fluctuations in discharge may temporarily alter brine deep temperatures and volumes. Alternatively, breaching of a larger fluid path might compensate for a lowered head and increase fluid flow over the long term.

The above hypothesizes large-scale flow and hence metal transport from nonevaporitic strata, presumably below the evaporites, conducted through evaporites in areas of separation or disruption, as in the rift zone. The hypothesis lends itself to testing especially in boreholes that penetrate the evaporite sequence, where fluids and evaporite samples can be recovered for investigation. Recharge of the fossil (M. Miocene) fluids by seepage from the present Red Sea is probable, but the recharging fluids entering at outcrop or subcrop positions on the flanks may or may not have reached the brine deeps up to the present.

\section{REFERENCES}

Ahmed, S. S., 1972. Geology and petroleum prospects of eastern Red Sea: Am. Assoc. Petrol. Geol. Bull., v. 56, p. 707.

Aumento, F., 1971. Vesicularity of mid-oceanic pillow lavas. Canadian J. Earth Sci., v. 8, p. 1315.

Bäcker, H. and Schoell, M., 1972. New deeps with brines and metalliferous sediments in the Red Sea: Nature, v. 240 , p. 153.

Baturin, G. N., Kochenov, A. V., and Trimonis, Ye. S., 1969. Composition and origin of the iron ore sediments and hot brines in the Red Sea: Oceanology (Okeanologiya in transl.), v. 9 , p. 360 .

Bischoff, J., 1969. Red Sea geothermal brine deposits: their mineralogy, chemistry, and genesis. In Degens, E. T. and Ross, D. A. (Eds.), Hot Brines and recent heavy metal deposits in the Red Sea: New York (Springer-Verlag), p. $368-401$.

Braitsch, O., 1971. Salt deposits, their origin and composition: New York-Heidelberg (Springer-Verlag).

Brewer, P. G. and Spencer, D. W., 1969. A note on the chemical composition of the Red Sea Brines. In Degens, E. T. and Ross, D. A. (Eds.), Hot brines and recent heavy metal deposits in the Red Sea: New York (Springer Verlag), p. 174.

Brewer, P. G., Riley, J. P., and Culkin, F., 1965. The chemical composition of the hot salty water from the bottom of the Red Sea: Deep-Sea Res., v. 12, p. 497.

Brewer, P. G., Wilson, T. R. S., Murray, J. W., Munns, R. G., and Densmore, C. D., 1971. Recent hydrographic observations on the Red Sea brines and a marked temperature increase: Nature, v. 231 , p. 37.

Brooks, R. R., Kaplan, I. R., and Peterson, M. N. A., 1969. Trace element composition of Red Sea geothermal brine and interstitial water. In Degens, E. T. and Ross, D. A. (Eds.), Hot brines and recent heavy metal deposits in the Red Sea: New York (Springer-Verlag), p. 180.

Craig, H., 1969. Geochemistry and origin of the Red Sea brines. In Degens, E. T. and Ross, D. A. (Eds.), Hot brines and recent heavy mineral deposits in the Red Sea: New York (Springer-Verlag), p. 208.

Culkin, F., 1965. The major constituents of seawater. In Riley, J. P. and Shirrow, G. (Eds.), Chemical oceanography, vol. 1: London (Academic Press), p. 121-161.

D'Ans, J., 1961. Uber die Bildungsmöglichkeiten des Tachhydrits in Kalisalzlagerstätten: Kali and Steinsalz, v. 3, p. 119.

Delevaux, M. H., Doe, B. R., and Brown, G. F., 1967. Preliminary lead isotope investigations of brine from the Red Sea, galena from the Kingdom of Saudi Arabia, and galena from United Arab Republic (Egypt): Earth Planet. Sci. Lett., v. 3, p. 139.

Deuser, W. G. and Degens, E. T., $1969 \mathrm{O}^{18} / \mathrm{O}^{16}$ and $\mathrm{C}^{13} / \mathrm{C}^{12}$ ratios of fossils from the hot-brine deep area of the central Red Sea. In Degens, E. T. and Ross, D. A. (Eds.), Hot brines and recent heavy metal deposits in the Red Sea: New York (Springer-Verlag), p. 336.

Faure, G. and Jones, L. M., 1969. Anomalous strontium in the Red Sea brines. In Degens, E. T. and Ross, D. A. (Eds.), Hot brines and recent heavy mineral deposits in the Red Sea: New York (Springer-Verlag), p. 243. 
Hackett, J. P. and Bischoff, J. L., 1973. New data on the stratigraphy, extent and geologic history of the Red Sea geothermal deposits: Econ. Geol., v. 68, p. 553-504.

Harder, H., 1970. Boron content of sediments as a tool in facies analysis: Sediment. Geol., v. 4, p. 153.

Hartmann, M. and Nielsen, H., 1966. Sulfur isotopes in the hot brine and sediment of Atlantis II Deep (Red Sea): Marine Geol., v. 4, p. 305.

Hassan, F. and El-Dashlouty, S., 1970. Miocene evaporites of Gulf of Suez region and their significance: Am. Assoc. Petrol. Geol. Bull., v. 54, p. 1686.

Hendricks, R. L., Reisbick, F. B., Mahaffey, F. J., Roberts, D. B., and Peterson, M. N. A., 1969. Chemical composition of sediments and interstitial brines from the Atlantis II, Discovery and Chain Deeps. In Degens, E. T. and Ross, D. A. (Eds.), Hot brines and recent heavy metal deposits in the Red Sea: New York (SpringerVerlag), p. 407.

Hodgson, G. W., 1965. Vanadium, nickel, and iron trace metals in crude oils of western Canada: Am. Assoc. Petrol. Geol. Bull., v. 49, p. 2537.

Holser, W. T., 1966. Diagenetic polyhalite in recent salt from Baja California: Am. Mineralogist, v. 51, p. 99.

Hsü, D. J., Cita, M. B., and Ryan, W. B. F., 1973. The origin of the Mediterranean evaporites. In Ryan, W. B. F., Hsü, K. J. et al., Initial Reports of the Deep Sea Drilling Project, Volume XIII: Washington (U. S. Government Printing Office), p. 1203.

Jones, J. G., 1969. Pillow lavas as depth indicators: Am. J. Sci., v. 267 , p. 181.

Kaplan, I. R., Sweeney, R. E., and Nissenbaum, A., 1969. Sulfur isotope studies on Red Sea geothermal brines and sediments: In Degens, E. T. and Ross, D. A. (Eds.), Hot brines and recent heavy metal deposits in the Red Sea: New York (Springer-Verlag), p. 474.

Korolev, D. F., 1958. The role of iron sulphides in the accumulation of molybdenum in sedimentary rocks of the reduced zone: Geokhimiya, v. 4, p. 452 (English Ed.).

$\mathrm{Ku}, \mathrm{T}-\mathrm{L} ., 1969$. Uranium series isotopes in sediments from the Red Sea hot-brine area. In Degens, E. T. and Ross, D. A. (Eds.), Hot brines and recent heavy metal deposits in the Red Sea: New York (Springer-Verlag), p. 512.

Kühn, R., 1953. Tiefenberechnung des Zechsteinmeeres nach dem Bromgehalt der Salze: Z. deutsche geol. Gesellschaft, v. 105, p. 646.

Landergren, S. and Manheim, F. T., 1962. Über die Abhängigkeit der Verteilung von Schwermetallen von der Fazies: Forschr. Geol. Rheinl. u. Westfalen, v. 10, p. 173.

Manheim, F. T., in press. Geochemical studies in the Red Sea. Shipboard analysis of rock and sediment samples: Saudi Arabia government publication, Kihlsgaard, T. H. (Ed.).

, in press. Interstitial waters of marine sediments. In Riley, J. P. and Chester, R. (Eds.), Chemical Oceanography: London (Academic Press).

Manheim, F. T., Sayles, F. L., and Waterman, L. S., 1971. Interstitial waters studies on small core samples, Deep Sea Drilling Project, Leg 8. In Tracey, J. I., Jr., et al., Initial Reports of the Deep Sea Drilling Project, Volume 8: (U. S. Government Printing Office), p. 857.
Manheim, F. T. and Waterman, L. S., in press. Diffusimetry (diffusion constant estimation) on sediment cores by resistivity probe. In von der Borch, C. C., Sclater, J. G., et al., Initial Reports of the Deep Sea Drilling Project, Volume 22: Washington (U.S. Government Printing Office).

Miller, A. R., Densmore, D. C., Degens, E. T., Hathaway, J. C., Manheim, F. T., McFarlin, P. F., Pocklington, R., and Jokela, A., 1966. Hot brines and recent iron deposits in deeps of the Red Sea: Geochim. Cosmochim. Acta, v. 30, p. 341 .

Milliman, J. D., Ross, D. A. and Ku, T-L., 1969. Precipitation and lithification of deep-sea carbonates in the Red Sea: J. Sediment. Petrol., v. 39, p. 724-736.

Moore, J. G., 1965. Petrology of deep-sea basalt near Hawaii: Am. J. Sci., v. 263, p. 40-52.

Neumann, A. C., and Chave, K., 1965. Connate origin proposed for hot salty bottom water from a Red Sea basin: Nature, v. 206, p. 1346.

Richter-Bernburg, G., 1953. Über salinare sedimentation: Zeitschrift Deutsch. geol. Gesellschaft, v. 105, p. 593.

Ross, D. A. and Schlee, J. S., in press. Shallow structure and geologic development of the southern Red Sea: Geol. Soc. Am. Bull.

Schmalz, P. R., 1969. Deep water evaporite deposition: a genetic model: Am. Assoc. Petrol. Geol. Bull., v. 53, p. 798.

Schoell, M. and Stahl, W., 1972. The carbon isotopic composition and the concentration of the dissolved anorganic carbon in the Atlantis II deep brines/Red Sea (sic): Earth Planet. Sci. Lett., v. 15, p. 206.

Shishkina, D. V. and Bogoyavlenskii, 1970. O solevom sostave glubinnykh vod Krasnogo morga: Geokhimiya, v. 5, p. 632 .

Valeyev, R. N., Ozol, A. A., and Tikhvinsky, I. N., 1972. Genetic characteristics of the halide-sedimentational type of borate deposits: Intern. Geol. Rev., v. 15, p. 165.

Vine, J. D., 1966. Element distribution in some shelf and eugeosynclinal black shales: U. S. Geol. Survey Bull., v. $1214 \mathrm{E}$, p. 31.

Vinogradov, A. P., 1967. Vvedenie v geokhimiyu okeana (Introduction to the geochemistry of the oceans), Moscow (Nauka).

Wardlaw, N. C., 1972. Unusual marine evaporites with salts of calcium and magnesium chloride in Cretaceous basins of Sergipe, Brazil: Econ. Geol., v. 67, p. 156.

Wedepohl, J. H., 1964. Untersuchungen am Kupferschiefer in Nordwestdeutschland: Ein Beitrag zur Duetung der Genese bituminöser Sedimente: Geochim. Cosmochim. Acta, v. 28, p. 305-364.

Weiss, R. F., 1969. Dissolved argon, nitrogen and total carbonate in the Red Sea brines. In Degens, E. T. and Ross, D. A. (Eds.), Hot brines and recent heavy mineral deposits in the Red Sea: New York (Springer-Verlag), p. 254.

Zaitsev, I. K., 1968. Analysis of main hypotheses for formation of salt water and brine in light of recent data: Int. Geol. Rev., v. 10, p. 1037. 